\title{
Antiviral and Virucidal Properties of Essential Oils and Isolated Compounds - A Scientific Approach
}

Author

Jürgen Reichling

\begin{abstract}
Affiliation
Formerly Institute of Pharmacy and Molecular Biotechnology, University of Heidelberg, Heidelberg, Germany
\end{abstract}

Key words

virus, virion, essential oil, essential oil compound, antiviral activity, virucidal effect

$\begin{array}{ll}\text { received } & \text { January 26, } 2021 \\ \text { accepted after revision } & \text { May 4, 2021 } \\ \text { published online } & \text { June 18, 2021 }\end{array}$

Bibliography

Planta Med 2022; 88: 587-603

DOI $10.1055 / \mathrm{a}-1382-2898$

ISSN 0032-0943

(C) 2021. Thieme. All rights reserved.

Georg Thieme Verlag KG, Rüdigerstraße 14,

70469 Stuttgart, Germany

Correspondence

Prof. Dr. Jürgen Reichling

Formerly Institute of Pharmacy and Molecular Biotechnology, University of Heidelberg

Keplerstraße 33, 69207 Sandhausen, Germany

Phone: + 4962242747, Fax: + 49622480427

juergen.reichling@t-online.de

Supplementary material is available under

https://doi.org/10.1055/a-1382-2898

\section{ABSTRACT}

Essential oils and isolated essential oil compounds are known to exert various pharmacological effects, such as antibacterial, antifungal, antiviral, anti-inflammatory, anti-immunomodulatory, antioxidant, and wound healing effects. Based on selected articles, this review deals with the potential antiviral and virucidal activities of essential oils and essential oil compounds together with their mechanism of action as well as in silico studies involving viral and host cell-specific target molecules that are indispensable for virus cell adsorption, penetration, and replication. The reported in vitro and in vivo studies highlight the baseline data about the latest findings of essential oils and essential oil compounds antiviral and virucidal effects on enveloped and non-enveloped viruses, taking into account available biochemical and molecular biological tests. The results of many in vitro studies revealed that several essential oils and essential oil compounds from different medicinal and aromatic plants are potent antiviral and virucidal agents that inhibit viral progeny by blocking different steps of the viral infection/replication cycle of DNA and RNA viruses in various host cell lines. Studies in mice infected with viruses causing respiratory diseases showed that different essential oils and essential oil compounds were able to prolong the life of infected animals, reduce virus titers in brain and lung tissues, and significantly inhibit the synthesis of proinflammatory cytokines and chemokines. In addition, some in vitro studies on hydrophilic nano-delivery systems encapsulating essential oils/essential oil compounds exhibited a promising way to improve the chemical stability and enhance the water solubility, bioavailabilty, and antiviral efficacy of essential oils and essential oil compounds.

\section{Viral Characteristics and Virus Replication Cycle}

Viruses are obligatory intracellular parasites that replicate and multiply (producing virions) inside host cells and spread outside cells via extracellular virions (cell-free virion spreading) [1]. Virions are not cells, but submicroscopic, metabolic inert, infectious, complex organic chemical particles of different size and structure [2].
On the other hand, it has been recognized in the last decade that virions (e.g., HIV-1, HSV-1, IFV, RSV) can also infect neighboring uninfected target cells by direct cell-cell contact (cell-tocell virion transmission) or by transmission in extracellular microvesicles (transport vesicles) released from infected host cells. By bypassing the extracellular space during reinfection of susceptible target cells, the viruses evade the body's immune response [1,3].

A complete virion or virus particle contains either DNA or RNA, which are usually surrounded by a protein shell that is known as capsid (non-enveloped viruses). Some virions are additionally sur- 


\begin{tabular}{|c|c|}
\hline \multicolumn{2}{|c|}{ ABBREVIATIONS } \\
\hline A549 & human lung carcinoma cells \\
\hline ACE2 & angiotensin-converting enzyme 2 \\
\hline AIDS & aquired immune deficiency syndrome \\
\hline AIV & avian influenza virus \\
\hline BVDV & bovine viral diarrhea virus \\
\hline bw & body weight \\
\hline CAM & chorio-allantoic membrane \\
\hline $\mathrm{CC}_{50}$ & half maximal cytotoxic concentration \\
\hline CLO & cedar leaf oil \\
\hline CMA & $\begin{array}{l}\text { Melaleuca alternifolia monoterpene } \\
\text { combination }\end{array}$ \\
\hline COVID-19 & coronavirus disease of 2019 \\
\hline CPE & (viral) cytopathogenic effect \\
\hline CRFK & Crandell-Reese feline kidney cells \\
\hline DENV & dengue virus \\
\hline DS & docking score \\
\hline dsDNA & double-stranded DNA \\
\hline $\mathrm{EC}_{50}$ & Fifty percent effective concentration \\
\hline EOCs & essential oil compounds \\
\hline EOs & essential oils \\
\hline FCV & feline calicivirus \\
\hline HA & hemagglutinin \\
\hline HEK 293T & human embryonic kidney cells \\
\hline HeLa & human cercial carcinoma cells \\
\hline HEp-2 & human laryngeal carcinoma cells \\
\hline HepG2 & human liver hepatocellular carcinoma cells \\
\hline HIV & human immunodeficiency virus \\
\hline HSV & herpes simplex virus \\
\hline HT-29 & human colon cancer cells \\
\hline i. p. & intraperitoneal(ly) \\
\hline i.v. & intravenous \\
\hline IC & inhibition concentration \\
\hline IFV & influenza virus \\
\hline $\mathrm{LD}_{50}$ & lethal dose, $50 \%$ \\
\hline M gene & $\begin{array}{l}\text { encodes for } \mathrm{M} 1 \text { and } \mathrm{M} 2 \text { proteins } \\
\text { in influenza virus }\end{array}$ \\
\hline M1 & matrix protein \\
\hline M2 & membrane protein \\
\hline MAC & Melaleuca alternifolia concentrate \\
\hline MARC-145 & African green monkey kidney cells \\
\hline MDBK & Madin-Darby bovine kidney cells \\
\hline MDCK & Madin-Darby canine kidney cells \\
\hline MNV-1 & Murine norovirus type 1 \\
\hline MOEO & Melissa officinalis essential oil \\
\hline $\mathrm{M}^{\mathrm{pro}} / 3 \mathrm{CL}^{\text {pro }}$ & chymotrypsin-like protease from SARS-CoV-2 \\
\hline MTEO & microencapsulated thyme essential oil \\
\hline NA & neuraminidase \\
\hline NP & nucleocapsid protein \\
\hline NS & viral nonstructural protein \\
\hline NS1 & viral nonstructural protein 1 \\
\hline PA & patchouli alcohol \\
\hline $\mathrm{PFU} / \mathrm{mL}$ & plaque forming units per milliliter \\
\hline PPV & porcine parvovirus \\
\hline RAW 264.7 & murine monocyte/macrophage-like cells \\
\hline
\end{tabular}

$\begin{array}{ll}\text { RBD } & \begin{array}{l}\text { receptor binding domain } \\ \text { RNase I }\end{array} \\ & \begin{array}{l}\text { ribonuclease I (endoribonuclease that } \\ \text { preferentially hydrolyzes single-stranded }\end{array} \\ \text { RNA to mononucleotides) } \\ \text { RSV } & \begin{array}{l}\text { respiratory syncytial viruses } \\ \text { real-time quantitative polymerase chain }\end{array} \\ \text { S glycoprotein } & \text { viral spike glycoprotein } \\ \text { SARS-CoV } & \text { severe acute respiratory syndrome } \\ & \text { coronavirus } \\ \text { SI } & \text { selectivity Index } \\ \text { SLN } & \text { solid lipid nanoparticle } \\ \text { SMEDI } & \text { stillbirth, mumification, embryonic death, } \\ \text { infertility } \\ \text { SSRNA } & \text { single-stranded RNA } \\ \text { TAR-RNA } & \text { trans-activating region at HIV RNA } \\ \text { Tat protein } & \text { trans-activator of transcription (essential } \\ & \text { protein for HIV transcription) } \\ \text { TCID } 50 & \text { tissue culture infectious dose that affect } \\ & \text { 50\% of the host cells } \\ \text { TEM } & \text { transmission electron microscopy } \\ \text { THQ } & \text { thymohydroquinone dimethyl ether } \\ \text { TMPRSS2 } & \text { transmembrane protease, serine 2 } \\ \text { TTO } & \text { tea tree oil } \\ \text { Vero cells } & \text { embryonic African green monkey kidney cells } \\ \text { VRNA } & \text { viral RNA } \\ \text { WNV } & \text { West Nile virus } \\ \text { WSSV } & \text { white spot syndrome virus } \\ \text { YFV } & \text { yellow fever virus } \\ & \end{array}$

rounded by a lipid envelope (lipid bilayer) in which the virus' own proteins are located (enveloped viruses) [4,5].

Virions have specific surface proteins with which they attach to the receptors on the respective host cell surface and can thus penetrate the cell. Inside the host cell, viruses generally use the cells' own energy and enzyme machinery in order to multiply [4, 6]. The steps involved in the virus propagation within the host cells are generally termed viral replication cycle. It follows a series of basic steps ( $\bullet$ Fig. 1 ) that are shared by many viruses: (1) Binding (attachment) of the virus particles to the host cell surface and subsequent penetration (entry) of the virus particles into the host cell: non-enveloped viruses by endocytosis or pinocytosis, enveloped viruses by fusion with the membrane of the potential host cell or by endocytosis; (2) uncoating of the nucleic acid of the virus; (3) multiplication (replication) of the nucleic acid of the virus (virus genome) in the cytoplasm or nucleus and formation of virus proteins in cytoplasm; (4) assembly and packaging of the components of the virus (genome and proteins) after transcription and translation; and (5) release (egress) of progeny infectious virions from the infected host cells into the intercellular area by budding (enveloped viruses), exocytosis (enveloped and non-enveloped viruses), or by lysis and bursting of the host cell. A detailed description of the individual stages of the replication cycles of different viruses with descriptive illustrations can be found in Rumlova et al. [4]. 


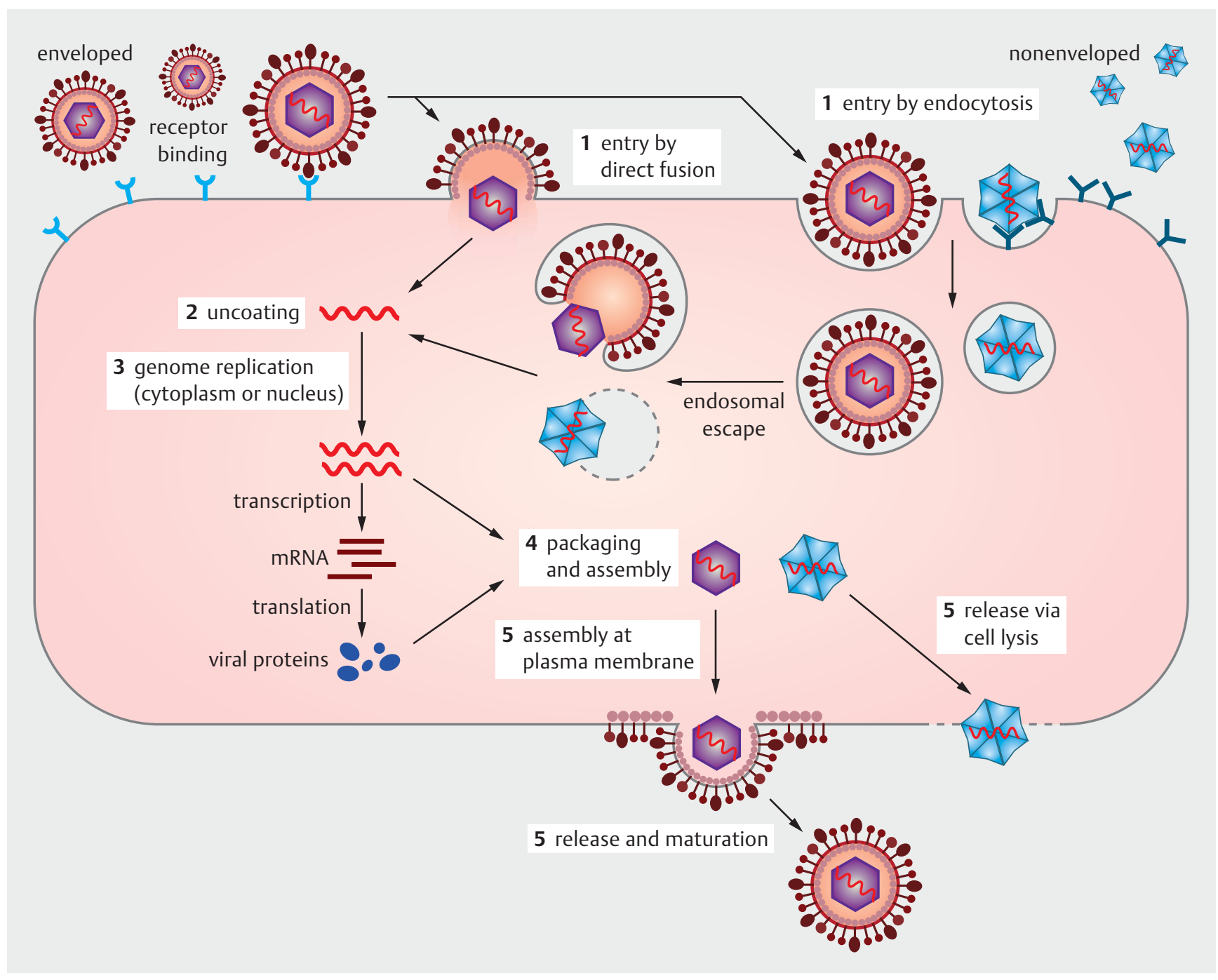

- Fig. 1 Common stages of the viral replication cycle in enveloped and non-enveloped viruses.

\section{Antiviral control}

In addition to vaccination, synthetic virucidal and antiviral substances are the backbone of efficient antiviral control [7]. Virucidal agents are antiviral substances that directly inactivate viral infectivity outside of host cells (intercellular space). Such compounds reduce or completely prevent the infectivity of cell-free virus particles. Antiviral agents are substances that directly inhibit the viral replication cycle (virus proliferation) inside the host cells and/or prevent the release of viruses from the cells into the intercellular space $[8,9]$. In order to overcome the emerging resistance, antiviral substances with new mechanisms of action are of great interest worldwide [10-12]. Against this background, phyto-antiviral compounds have also come into the focus of research. In the past, EOs, aqueous and alcoholic extracts of medicinal plants as well as isolated secondary plant metabolites have been tested for their potential antiviral properties against human and animal pathogenic viruses [8,13-22].

\section{Chemical Characteristics and Biological Effects of Essential Oils}

Plant-derived EOs are mixtures of different lipophilic, low molecular, aromatic, volatile compounds, which usually consist of monoterpenes, sesquiterpenes, and phenylpropanes ( $>$ Fig. 2) and their oxygenated derivatives (alcohols, aldehydes, esters, ketones, phenols, and oxides) [13,23-25]. Numerous in vitro and in vivo studies have shown that EOs and many of their individual EOCs exhibit different biological properties, for example, antibacterial $[13,23$, 25], antifungal [13], antiviral [13], antioxidant [26, 27], immunomodulatory $[28,29]$, anti-inflammatory $[24,27]$, and wound healing effects [30]. Due to their fat solubility, low molecular weight, and small size, the EOCs are able to pass through the skin, mucosa, and cell membranes and thus enter the systemic body circulation $[13,24]$. 


\section{$\underbrace{\mathrm{CH}_{\mathrm{CH}}^{\mathrm{CH}_{3}}}_{\mathrm{CH}_{3}}$}

1,8-Cineole<smiles>CC(C)=C1CC[C@@H](C)CC1=O</smiles>

Pulegone<smiles>C=CCc1ccc(O)c(OC)c1</smiles>

Eugenol<smiles>CC(C)[C@H]1CC[C@@]2(C)O[C@H]2C1=O</smiles>

Piperitenone oxide<smiles>CC1=CCC(=C(C)C)C(=O)CC=C1</smiles>

Germacrone<smiles>Cc1ccc(C(C)C)cc1O</smiles>

Carvacrol<smiles>CC1=CCC(O)(C(C)C)CC1</smiles>

Terpinen-4-ol<smiles>CC1=CCC(=C(C)C)CC1</smiles>

Terpinolene<smiles>CC1=CCC(C(C)(C)O)CC1</smiles>

$\alpha$-Terpineol<smiles>O=C/C=C/c1ccccc1</smiles>

Cinnamaldehyde

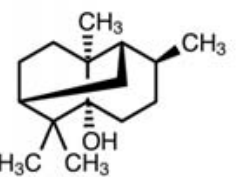

Patchouli alcohol<smiles>C=C1C2CCC(C2)C1(C)CC/C=C(/C)CO</smiles>

$\beta$-Santalol<smiles>Cc1ccc(C(C)C)cc1</smiles>

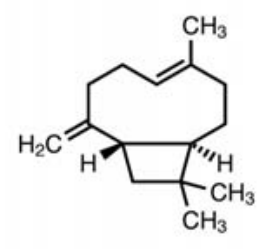

$\beta$-Caryophyllene

- Fig. 2 Selection of some most prominent EOCs with antiviral properties.

The following review article deals mainly with the in vitro virucidal and antiviral activity of EOs and some EOCs against enveloped (Table 1S, Supporting Information) and non-enveloped (Table 2S, Supporting Information) pathogenic human and animal viruses (Table 3S, Supporting Information), especially taking into account the data and results of the past 10 years. The particular focus lies on the mode of action of the tested EOs (Table 4S, Supporting Information) and EOCs, whereby more recent findings on special viral targets are to be presented in more detail. In vivo studies with animal models, wherever possible, complement the in vitro studies.

\section{Search Strategy, Evaluation, and Limitations of Literature}

\section{Search strategy}

Because most peer-reviewed articles are listed in the databases PubMed, Google Scholar, and BASE (Bielefeld Academic Search Engine), they were used for the initial literature research. Under the heading "antiviral activity of essential oils", 127 articles in PubMed, 62 articles in Google Scholar, and 209 articles in BASE were found for the years between 2010 to 2020. Furthermore, the literature from reference lists of all the papers selected were also examinded for their relevance to the topics. The Google search engine was also used to find relevant articles.

\section{Evaluation and limitation of literature}

In the past decade, numerous in vitro experimental studies on the topic of EOs and EOCs with virucidal and antiviral activities have been published, with a significant increase in publication activity from 2015 to 2020. The focus of this review lies, on the one hand, on important enveloped viruses that cause endemic and/or pandemic diseases such as ZKV, IFV-A, RSV, HIV-1, hepatitis B virus, Ebola virus, SARS-CoV-2, noroviruses, dengue viruses, and West Nile fever virus and, on the other hand, on the non-enveloped viruses such as coxsackievirus, murine norovirus, rhinovirus, rotavirus, feline calicivirus, and some bacterial phages (s. Table 3S, Supporting Information). All these viruses show a range of viral characteristics, including the presence or absence of a lipid envelope, different forms of genomes (DNA or RNA), and different tissue/organ tropisms.

Up to now, the mechanisms of action of the antiviral activity of EOs and EOCs have not yet been fully understood and are therefore not always adequately presented in review articles. In order to gain a deeper insight into the antiviral mode of action of EOs and EOCs, modern biochemical, molecular biological, and electron optical methods (e.g., TEM imaging), cell-binding experiments, RNase I protection experiments, RT-qPCR methods as well as in silico molecular docking experiments (computer simulations) have been used increasingly in the past decade. In order to assess the therapeutic potential of certain compounds, the interaction between the ligands and the protein at the molecular level must be known. In silico studies reduce the time needed to identify new lead bioactive molecules [4]. In addition, in recent years, a few studies have already evidenced the great antiviral potency of 
some EOs and EOCs on certain non-enveloped viruses using adequate experimental methods.

This review article therefore focuses not only on the endless listing of relevant studies of the past decade. Rather, the mode of antiviral action of bioactive EOs and EOCs will be described wherever possible on the basis of selected scientific literature. In addition, some relevant animal studies are also discussed in more detail.

\section{In Vitro Methods Commonly Used to Deter- mine the Virucidal and Antiviral Activities of Essential Oils and Essential Oil Compounds and Their Mode of Action}

\section{Evaluation of in vitro virucidal and antiviral activities}

The methods commonly used for the evaluation of in vitro antiviral activities of EOs and EOCs are mainly based on the inhibition of $\mathrm{CPE}$, the reduction or inhibition of plaque formation, and reduction in the virus yield, as well as on other viral functions in selected host cell cultures [12].

\section{Mechanisms of action}

Time-of-drug-addition assays and temperature-shift assays are performed to determine particular steps in the viral infection/replication cycle in cell-based systems, such as entry events (e.g., viral attachment, fusion, uncoating), replication phase (viral genome replication, viral protein translation), and virion egress (assembly, maturation, release) that can be inhibited by potential antiviral substances. Here, the methods are only descibed in brief; more detailed information can be found in the cited literature [4, $6,12,31-33]$.

\section{Time-of-drug-addition assays}

Pretreatment of host cells

Cultured cells (cell monolayer) are first pretreated with different concentrations of an antiviral substance prior to inoculation (infection) with virions. The assay examines whether the antiviral substance prevents viral attachment to the host cells.

\section{Pretreatment of cell-free virions}

Virions are first incubated with different concentrations of an antiviral substance outside of the host cells followed by direct inoculation of the treated virions to the cells. The assay examines the virucidal or neutralizing activity of the antiviral substance.

\section{Co-treatment of cells and virions during virus inoculation/cell infection}

Virions mixed with different concentrations of an antiviral substance are directly inoculated to the host cells. The assay examines the antiviral effect of the test substance on the virion entry steps.

\section{Post-entry treatment}

Host cells are initially inoculated with virions to allow virion entry. Subsequently, the virus-infected cells are treated with the antiviral substance. The assay examines whether the antiviral test substance can interfere with the intracellular virus replication cycle.

\section{Temperature-shift assays}

Viral attachment (binding) assay

Prechilled host cells are incubated with a mixture of virions and test substances at $4^{\circ} \mathrm{C}$. After washing, the host cells are shifted to $37^{\circ} \mathrm{C}$ (without test substances) to allow virus internalization. A positive result (e.g., reduction of plaque formation) means that the antiviral substance prevents the attachment of virions to the cell membrane.

Viral entry/fusion assay

Virions are added to prechilled host cells at $4{ }^{\circ} \mathrm{C}$, permitting viral binding to the cell membrane but not to entry. Subsequently, the virion incubated cells are washed in order to remove unbound virions and then treated with test substances at $37^{\circ} \mathrm{C}$. A positive result (e.g., reduction of plaque formation) means that the antiviral substance inhibits the entry of the virion (penetration) into host cells.

\section{Selectivity index}

The $\mathrm{SI}$ is a ratio that measures the window between cytotoxicity $\left(\mathrm{CC}_{50}\right)$ and antiviral activity $\left(\mathrm{IC}_{50}\right)$ of an antiviral test compound by dividing the specified $\mathrm{CC}_{50}$ value by the $\mathrm{IC}_{50}$ value $\left(\mathrm{SI}=\mathrm{CC}_{50} /\right.$ $I_{50}$ ). An ideal antiviral compound would be cytotoxic only at very high concentrations and have antiviral activity at very low concentrations. An SI value of 4 or more is appropriate for an antiviral agent [34].

\section{Antiviral Activity of Essential Oils and Essential Oil Compounds against Enveloped Viruses}

A subjective selection of interesting scientific works on this topic from the last decade is summarized in Table 1S, Supporting Information. All of the listed viruses and EOs are summarized and characterized in Tables 35 and 4S, Supporting Information, respectively. Some scientific papers are covered below in more depth to give the readers an insight into the antiviral mode of action of EOs and isolated oil components in cell-based assays (in vitro) and, in some cases, also in animal models (in vivo).

\section{Influenza viruses}

IFVs are enveloped RNA viruses that are classified as type $A$, B, or $C$ by $\mathrm{HA}$ and NA proteins. Only IFV-A and IFV-B are dangerous to the health of human beings [35]. The structure and replication cycle of IFV are described in detail by Samji [36].

\section{Influenza viruses in liquid phase}

The antiviral effect of TTO and its active components were explored in vitro on IFV A/PR/8 (H1N1) in MDCK cells [39]. It was demonstrated that the test compounds (TTO at $0.01 \%$, terpinen4-ol at $0.01 \%$, terpinolene at $0.005 \%$, $\alpha$-terpineol at $0.02 \%$ ) inhib- 
ited early events in the virus replication cycle when added to the cells within $1 \mathrm{~h}$ after the end of the virus adsorption period to MDCK cells. The virus titer was reduced by 70 to $100 \%$. However, no further reduction in the virus replication was observed if the substances were added to the host cells later than $2 \mathrm{~h}$ after virus adsorption. Further experiments demonstrated that TTO and its components did not interfere with the cellular attachment of the virus nor did it inhibit the IFV neuraminidase activity or show any virucidal effects [39]. It has been shown in literature that the acidic condition in endosomes and lysosomes is essential for the uncoating process of the IFV inside infected host cells $[40,41]$. The treatment of MDCK cells with TTO and terpinen-4-ol at $0.01 \%$ at $37^{\circ} \mathrm{C}$ for $4 \mathrm{~h}$ inhibited the acridine orange accumulation in cytoplasmic vesicles (cellular endosomes/lysosomes), indicating an inhibitory effect of the test compounds on the acidification of these intracellular compartments. The result obtained was concordant with the positive control bafilomycin A1 (autophagy inhibitor) at $100.0 \mathrm{nM}$. From these experiments, the authors concluded TTO and terpinen-4-ol could potentially inhibit IFV-A replication intracellularly by inhibiting the uncoating of the viruses [39].

Li et al. [42] examined the anti-IFV (IFV-A/2009/H1N1) activity of a MAC mainly consisting of terpinen-4-ol (56-58\%), $\gamma$-terpinene $(20.65 \%)$, and $\alpha$-terpinene $(9.80 \%)$. When cell-free IFV-A particles were incubated by $0.01 \%$ MAC for $1 \mathrm{~h}$ prior to MDCK cell infection, no cytopathic effects on host cells were detected. In addition, electron microscopic studies showed that MAC in the virucidal concentration of $0.01 \%$ did not damage the virus envelope. But in an in silico molecular docking experiment, the authors could demonstrate that terpinen-4-ol, the main constituent of MAC, could bond very strongly to the receptor (membrane fusion) site of HA of IFV-A (s. Table 1S, Supporting Information). The authors concluded from these experiments that MAC prevented viruses from entering the cells by disrupting the normal fusion process between virions and host cells.

Wu et al. [43] investigated the anti-IFV-A (H2N2) properties of $\mathrm{PA}$ in in vitro, in vivo, and in silico experiments. $\mathrm{PA}$ is a sesquiterpene alcohol, which is the major constituent of patchouli oil derived from the aerial part of Pogostemon cablin (Blanco) Benth. Posttreatment of virus-infected cells with PA resulted in a strong reduction of the viral replication inside MDCK cells, with an $\mathrm{IC}_{50}$ value of $4.03 \mu \mathrm{M}$ (SI: 4.96). The antiviral activity was time and concentration dependent. In the nontoxic concentration of $8.0 \mu \mathrm{M}$, the compound inhibited the virus replication in a time-dependent manner, with a maximum inhibition of $97.68 \%$ after $72 \mathrm{~h}$ of incubation. In contrast to this result, no effects were seen when PA was used for the pretreatment of cells or virions or when the compound was added during the virion adsorption phase. On the other hand, an in silico molecular docking experiment revealed a strong chemical bond of PA to the active site of the viral NA protein (s. Table 1S, Supporting Information). NA plays a crucial role in the release of newly formed progeny IFVs from the cell membrane of infected host cells into the intercellular space (e.g., nasal epithelium) [44]. In addition, in a mouse model, PA protected the test animals from an influenza infection at a concentration of $5.0 \mathrm{mg} / \mathrm{kg} /$ day. Mice were infected by intranasal instillation; oral treatment daily for 5 days; 10 animals in total. Result (survivors/ total): PA 7/10 animals; oseltamivir ( $1.0 \mathrm{mg} / \mathrm{kg} /$ day) 5/10 animals; infected control 0/10 animals.

Recently, the antiviral activity of PA on three different IFV-A types, H1N1 (A/Puerto Rico/8/34), H1N1 (A/NWS/33), and H1N1 (A/Virginia/ATCC1/2009), was reexamined in in vitro and in vivo experiments [45]. PA exerted its antiviral activity in vitro by direct inactivation of cell-free virus particles, with $\mathrm{IC}_{50}$ values of $6.1,3.5$, and $6.3 \mu \mathrm{g} / \mathrm{mL}$, respectively, as well as by inhibiting the early steps of viral replication in MDCK cells. The virucidal effect of PA was not based on a direct interaction with the NA and HA proteins on the virus surface. Therefore, it can be speculated that the virucidal effect of PA can be caused by a destruction of the viral envelope. The inhibition of the early steps in the viral life cycle could also be explained by a reduced viral RNA and protein expression. In cells that were treated with PA $(40.0 \mu \mathrm{g} / \mathrm{mL})$ after virus infection (posttreatment of virus-infected cells), the viral NP mRNA level and NP protein synthesis were significantly reduced by about 86 and $80 \%$, respectively. IFV NPs are proteins that are associated with vRNA to form nucleocapsids. In an in vivo experiment (mouse pneumonia model), mice were first inoculated intranasally with IFV-A (A/PR/8/34) and subsequently divided into different experimental groups. Four hours after inoculation, 10 mice per group received intranasal PA (20.0 or $40.0 \mu \mathrm{g} /$ day) or placebo or oral oseltamivir phosphate $(10.0 \mathrm{mg} / \mathrm{kg} /$ day $)$; these treatments were repeated once daily for 4 or 7 days. In contrast to the control groups, the PA treatment $(40.0 \mu \mathrm{g} / \mathrm{mL})$ significantly reduced the pulmonary virus titer (from about $5.0 \times \log _{10} \mathrm{PFU} / \mathrm{mL}$ to about $3.0 \times \log _{10} \mathrm{PFU} / \mathrm{mL}$ ), increased the survival time of the infected mice (survival time 14 days post-infection: placebo group: $30 \%$; verum group $100 \%$ ), and reduced the symptoms of pneumonia. The effects were comparable to that of oseltamivir [45].

Paulpandi et al. [46] investigated the anti-IFV activity (IFV-A/ $\mathrm{HK} / \mathrm{H} 3 \mathrm{~N} 2$ ) and the inhibition of viral RNA synthesis in MDCK cells caused by $\beta$-santalol. The compound was isolated from the essential sandalwood (Santalum album L.) oil. In a co-treatment assay (cells + virions), $\beta$-santalol reduced the virus-induced formation of CPE by $86 \%$ in a concentration of $100.0 \mu \mathrm{g} / \mathrm{mL}$. In addition, using the RT-PCR method, the authors could also demonstrate a complete inhibitory effect of $\beta$-santalol (at $100.0 \mu \mathrm{g} / \mathrm{mL}$ ) on the late viral RNA synthesis of the M gene. The antiviral effect of $\beta$ santalol was comparable to oseltamivir (CPE reduction by $83 \%$ at $100.0 \mu \mathrm{g} / \mathrm{mL}$ ) in the same test system. Additional note: The M gene encodes for two proteins, M1 (matrix protein) and M2 (membrane protein). There are indications that the $\mathrm{M}$ gene may be involved in determining host tropism (ability to infect a specific tissue) [47]. Furthermore, IFV-A M2 is able to block the fusion of autophagosomes with lysosomes [48]. Dai et al. [50] screened natural compounds for their inhibitory effects on viral autophagy. IFVs promote the multiplication of autophagosomes containing IFV particles. The viruses block the fusion of autophagosomes and lysosomes and therefore they can escape the immune system [51]. Eugenol, the main compound of essential clove (Syzygium aromaticum (L.) Merr. \& L. M. Perry) oil, was found to be a potent anti-autophagy agent at the maximal non-cytotoxic concentration of $5.0 \mu \mathrm{g} / \mathrm{mL}$ (cell culture: A549 cells). Eugenol not only inhibited the viral autophagy, but also reduced the expression of autophagic genes (measured at both the mRNA and protein levels) in- 
duced by viruses. The anti-IFV-A activity (posttreatment of virusinfected cells) was measured by using a plaque reduction assay in MDCK cells. The best result was achieved 1-3 h post-infection with an $\mathrm{EC}_{50}$ value of $0.6392 \mu \mathrm{g} / \mathrm{mL}$; SI- value: 117.8 . In addition, eugenol $(5.0 \mu \mathrm{g} / \mathrm{mL})$ significantly inhibited the release of the cytokines TNF- $\alpha$, IL-1, IL-6 and IL-8 [50].

Germacrone, a sesquiterpene oxide from the EO of Curcumae xanthorrhizae rhizoma, inhibited, in a co-treatment assay, the IFV-A/PR/8/34(H1N1) replication in MDCK cells in a dose-dependent manner with an $\mathrm{EC}_{50}$ value of $6.03 \mu \mathrm{M}$ [52]. In addition, germacrone also inhibited the replication of other IFA viruses such as influenza A/human/Hubei/1/2009(H1N1), A/human/Hubei/3/ 2005(H3N2), A/human/WSN/33(H1N1,S31N, amantadine resistant), and influenza $B /$ human/Hubei/1/2007 in a dose-dependent manner (for MDCK cells: $\mathrm{ED}_{50}$ values of $3.82-7.12 \mu \mathrm{M} / \mathrm{SI}$ values > 41.0; for A549 cells: $E_{50}$ values of $2.15-4.78 \mu \mathrm{M} / \mathrm{SI}$ values 93.9) [52]. Furthermore, germacrone blocked several early steps (up to $4 \mathrm{~h}$ post-viral infection) of IFV-A/PR/8/34(H1N1) replication in MDCK cells as shown by time-of-drug-addition assays and temperature-shift assays. It also impaired the attachment and penetration of IFV-A into the host cells. In addition, the compound reduced the viral RNA synthesis, protein synthesis, and production of infectious progeny virions in MDCK cells in a dose-dependent manner (similar to Ribavirin) [52].

$\mathrm{BALB} / \mathrm{C}$ mice were intranasally infected with $5 \times \mathrm{LD}_{50}$ of IFV-A/ $\mathrm{PR} / 8 / 34$ (H1N1). Germacrone (50.0 or $100.0 \mathrm{mg} / \mathrm{kg}$ ) was administered intravenously once daily for 5 days, starting $24 \mathrm{~h}$ before virus exposure. The survival of the infected animals (16 in each group) was monitored daily for 18 days. Germacrone exhibited an effective survival of mice by $50 \%$ when $100.0 \mathrm{mg} / \mathrm{kg}$ germacrone were administered. In addition, the test compound at $100.0 \mathrm{mg} / \mathrm{kg}$ significantly reduced the virus titers in the lungs of the mice without killing or intoxicating the animals [52].

In an animal study [54], the effect of 1,8-cineole (in $0.5 \%$ Tween 80 ) in concentrations of $30.0,60.0$, and $120.0 \mathrm{mg} / \mathrm{kg}$ on mice infected with influenza A virus/Font Monmouth/47 (H1N1) was evaluated (IFV control group: IFV + saline in $0.5 \%$ Tween 80 ; positive control group: oseltamivir $10.0 \mathrm{mg} / \mathrm{kg}$ ). Mice were inoculated intranasally with the virus particles. First, the mice were treated orally with 1,8-cineole or oseltamivir for 2 days before viral infection and for 5 days after viral infection. The survival time was monitored for 15 consecutive days in all of the test groups. In contrast to the IFV control group (IFV-Co), 1,8-cineole treatment significantly prolonged the survival time of the mice after virus infection (survival time: IFV-Co: 5 days; 1,8-cineole $(60.0 / 120.0 \mathrm{mg} /$ kg) group: 10 days) [54]. In addition, the test compound reduced at 60.0 and $120.0 \mathrm{mg} / \mathrm{kg}$ the expression of the nuclear factor- $\kappa \mathrm{B}$, the intercellular adhesion molecule- 1 , and the vascular cell adhesion molecule- 1 in mice lung tissues. Furthermore, it reduced the levels of proinflammatory cytokines such as IL-4, IL-5, IL-10, and MCP- 1 in nasal lavage fluids and IL- $1 \beta$, IL-6, TNF- $\alpha$, and IFN- $\gamma$ in lung tissues of mice and relieved the pathological changes of viral pneumonia in IFV-A-infected mice. The authors argued that 1,8cineole protects mice from IFV-A by means of attenuation of pulmonary inflammatory responses [54].

Choi [55] investigated 63 plant EOs for their anti-influenza (IFV-A/WS/33) properties using MDCK cells and a CPE assay (co- treatment of cells and virions with test oils during virus inoculation). The most active EOs were anise oil, marjoram oil, and clary sage oil. At a concentration of $100.0 \mu \mathrm{g} / \mathrm{mL}$, the EOs exhibited an anti-IFV-A effect by more than $53.0 \%$ (CPE reduction) without any cytotoxic side effects.

\section{Influenza virus in ambient air (airborne viruses)}

In principle, IFVs can be transmitted from person to person through the air via aerosols or large respiratory droplets and via direct contact with secretions [56]. In an animal model (ferrets), it has recently been shown that influenza A viruses (H1N1/H3N2/ $\mathrm{H} 5 \mathrm{~N} 1$ ) are transmitted specifically via the air from the nasal respiratory epithelium, and not from the trachea, bronchus, or the lungs [57]. Against this background, EO aerosols and vapors can have positive effects on human health in enclosed rooms and working spaces.

The main aim of the following study was to investigate the antiviral activity of TTO and eucalyptus oil aerosols and vapors against airborne influenza A virus (NWS/G70C/H11N9). TTO, when actively diffused with a nebulizer for $2 \mathrm{~s}$, cleared nearly all airborne IFV-A after $10 \mathrm{~min}$, and showed zero virus after $15 \mathrm{~min}$ post-nebulizer treatment. Blue mallee (Eucalyptus polybractea $\mathrm{F}$. Muell. ex R. T. Baker) oil showed zero virus after 15 min following a 15 -s period of active diffusion with a nebulizer. Compared to the aerosols, the corresponding vapors of both EOs were less effective [58].

Vimalanathan and Hudson [59] investigated the anti-influenza virus (IFV-A/Denver/1/57/H1N1) activities (virucidal activities) of EOs and EOCs of Cinnamomum zeylanicum Blume, Citrus bergamia Risso, Cymbopogon flexuosus (Nees ex Steud.) W. Watson, Eucalyptus globulus Labill., Pelargonium graveolens L'Hér., Thymus vulgaris L., and some other plants in both the liquid and vapor phase using MDCK and A549 cells as host cell lines. The best results in the liquid phase were exhibited by the EOs of $C$. zeylanicum, $C$. bergamia, C. flexuosus, and T. vulgaris and eugenol; they inactivated the cell-free virions by $100 \%$ (plaque reduction) at $3.1 \mu \mathrm{L} / \mathrm{mL}$. In the liquid phase, the EOs of $C$. bergamia and E. globulus as well as the isolated EOCs citronellol and eugenol inhibited virus infectivity by 90-100\% after exposure of the virus to $250 \mu \mathrm{L}$ test substance per test tube for $10 \mathrm{~min}$. In both cases, the test compounds were not toxic on epithelial cell monolayers. In addition, in the vapor phase, the test compounds were able to inhibit HA activity. The authors concluded that the anti-influenza properties of these compounds were based on the interaction of EOs with $\mathrm{HA}$.

\section{Avian influenza virus}

AIV is a variety of influenza A virus that has adapted to birds as host animals (e.g., chickens, turkeys, geese, ducks, wild waterfowl). It causes the so-called avian flu or bird flu. The AIV-A subtype H9N2 is found in all of Eurasia among land birds. Although the virus is not highly pathogenic, it causes severe economic losses and even the death of the birds [62].

Pourghanbari et al. [64] investigated the antiviral effect of lemon balm oil on the AIV (AIVA/turkey/Wisconsin/1/66/H9N2) at different concentrations ( 0.5 to $0.005 \mathrm{mg} / \mathrm{mL}$ ). Time-of-addition assays showed that lemon balm oil was able to inhibit various stages of the viral replication cycle in MDCK cells. The best results 
were obtained when virions were pretreated with 0.5 and $0.1 \mathrm{mg} /$ $\mathrm{mL}$ prior to host cell infection (reduction of the virus titer of about $85 \%)$. The results were comparable with the oseltamivir control $(0.5 \mathrm{mg} / \mathrm{mL}$ for $85 \%$ virus titer reduction). The reduction of virus replication was based on the reduction of RNA synthesis measured by an RT-PCR test.

In a standardized protocol for quantitative evaluation of antiaerosolized AIV-A H9N2 activity by vapors of a well-characterized EO blend (using constructed impingers/glass chambers), Kumosani et al. [65] showed that in contrast to the control (viral particles count: $\left.1.2 \times 10^{6} / \mathrm{cm}^{3}\right)$, within 1.5 min of contact time, a vaporized EO blend (equivalent volumes of eucalyptus oil with $42.2 \%$ 1,8-cineole and peppermint oil with $48.7 \%$ menthol) reduced the virus titer (aerosolized viruses) by about $84.6 \%$ at a concentration of $1.0 \times 10^{-4} \mu \mathrm{L} \mathrm{EO} / \mu \mathrm{L}$ air volume.

Shayeganmehr et al. [66] examined the EO of Zataria multiflora Boiss. for its anti-AIV-A H9N2 activity in virus-infected broilers. The virus replication in the respiratory and gastrointestinal tracts of the animals was explored using RT-qPCR. Broiler chicks (21 days old) received 20.0 or $40.0 \mu \mathrm{L} / \mathrm{kg}$ bw/day Zataria oil (dissolved in corn oil) before or after (2 days) virus infection. Another group of chicks got $4.0 \mathrm{mg} / \mathrm{kg}$ bw/day amantadine (dissolved in corn oil), a known antiviral agent, from 2 days after virus challenge concurrent with the onset of H9N2 symptoms. The control group received only corn oil in the same concentration as the verum groups. All test compounds were administered per os. Broiler chickens treated with Zataria oil, before or after infection with viruses, and the amantadine group showed a significant reduction of the viral replication (decreased viral load) in the respiratory and gastrointestinal tracts compared to the control group. Overall, Zataria oil was slightly better than amantidine.

\section{Severe acute respiratory syndrome coronavirus 2}

SARS-CoV-2 is a novel enveloped RNA betacoronavirus that is closely related to the SARS-CoV from 2003 (SARS-CoV-1) and is known to cause the viral disease COVID-19. It first emerged in Wuhan, China, and is presently causing a global pandemic. The virus can be transmitted from person to person by droplets or aerosols, as well as by physical contact [67]. In recent months, increased efforts have been made to identify new antiviral and virucidal substances that can prevent or at least mitigate a SARS-CoV-2 infection. In this context, numerous extracts and isolated individual substances from medicinal plants have been investigated in vitro and in silico for their potential antiviral properties, such as EOs and isolated oil components [28,68-75].

ACE2 is an integral membrane glycoprotein that is known to be expressed in most human tissues such as kidneys, endothelium, lungs, and heart. ACE2 is the host cell entry receptor for SARSCoV-2. Therefore, if the ACE2 protein can be inhibited, cells can be protected temporarily from infection with SARS-CoV-2. Recently, several in silico studies were carried out to screen for EOCs that can block the activity of ACE2 as a receptor for SARS-CoV-2. Abdelli et al. [77] investigated isothymol, thymol, limonene, $p$ cymene, and $y$-terpinene, characteristic compounds of Ammoides verticillata (Desf.) Briq., for docking experiments. Isothymol demonstrated the best result of all the compounds tested in binding to the ACE2 active site (s. Table 1S, Supporting Information). Fur- thermore, organosulfur compounds (allyl disufide, allyl trisulfide) in garlic EO [78], (E,E)- $\alpha$-farnesene, (E)- $\beta$-farnesene, (E,E)-farnesol [79] as well as terpineol, guaiol, linalool, 1,8-cineole, $\beta$-selinenol, $\alpha$-eudesmol, and $\gamma$-eudesmol, typical compounds in Melaleuca cajuputi Powell EO [80], also displayed a strong binding affinity to the human ACE2 cell receptor in in silico experiments (s. Table 1S, Supporting Information).

Kumar et al. [81] explored 30 EOs for their ability to downregulate the ACE2 receptor in HT-29 epithelial cells. Among them, geranium and lemon oils exerted significant ACE2 inhibitory effects in vitro. Geranium oil inhibited the ACE2 activity at $50 \mu \mathrm{g} /$ $\mathrm{mL}$ by $89.37 \%$ and lemon oil at $25 \mu \mathrm{g} / \mathrm{mL}$ by $75.21 \%$. Immunoblotting and an ELISA assay revealed a significant decrease of ACE2 protein expression and RT-qPCR a significant downregulation of the corresponding mRNA level in HT-29 cells. In addition, citronellol, limonene, and geraniol also downregulated the ACE2 receptor as well as the protein expression and mRNA level in HT29 epithelial cells.

The main viral protease $\mathrm{M}^{\mathrm{pro}} / 3 \mathrm{CL}^{\text {pro }}$ is part of the SARS CoV-2 replication cycle. This proteolytic enzyme processes the coherent "polyproteins" into functional single molecules. Therefore, it has recently been regarded as a suitable target for a drug design against SARS CoV-2 infections [28]. Recently several in silico molecular docking experiments have shown that 1,8-cineole (eucalyptol) from Eucalyptus globulus Labill. [82], jensenone (4,6-diformyl-2-isopentanoylphloroglucinol) from Eucalyptus jenseni Maiden [83], carvacrol from Origanum vulgare L. and Thymus vulgaris [84], organosulfur compounds (allyl disulfide, allyl trisulfide) from Allium sativum L. [78] as well as terpineol, guaiol, linalool, 1,8 -cineole, $\beta$-selinenol, $\alpha$-eudesmol, and $\gamma$-eudesmol from $M$. cajuputi [80] very effectively bound to the main SARS-CoV-2 proteinase (s. Table 1S, Supporting Information).

The spike protein ( $\mathrm{S}$ glycoprotein) consists of two subunits, namely, the S1 unit, which is also known as the RBD, and the S2 unit. The virus binds to the ACE2 receptor of the host by means of the S1 subunit; the S2 subunit is responsible for the fusion of the virus envelope and the host cell membrane [85]. The RBD seems to be of clinical relevance, since blocking this domain will probably lead to the first step of a virus infection being prevented [86].

Kulkarni et al. [86] investigated 25 monoterpenes and phenylpropanoids for their binding affinities to the virus RBD using in silico molecular docking experiments. The authors found that anethole, cinnamaldehyde, carvacrol, geraniol, cinnamyl acetate, $\alpha$-terpineol, thymol, and pulegone, all components of EOs from different plant families, effectively bound to the S1 RBD of the spike (S) glycoprotein (s. Table 1S, Supporting Information)

In addition, the human serine protease TMPRSS2 is another important protein involved in the binding of ACE2 and the spike protein. This protease primes the spike protein before it binds to ACE2. It was found that trans-pinocarveol, eucalyptol, menthol, linalool, $\alpha$-pinene, and methyl salicylate docked to TMPRSS2 with an average binding energy value of $-4.2 \mathrm{kcal} / \mathrm{mol}$. Of the tested substances, methyl salicylate was of particular interest as it bound to TMPRSS2 on the same site as the known TMPRSS2 inhibitory drug camostat (protease inhibitor) [87]. 
However, it must be critically noted that EOs and EOCs as COVID-19 antiviral agents are still limited to in vitro and molecular docking research or to computer simulations conducted by equating the active substance molecules in EOs with the SARSCoV-2 virus protein molecules. Hitherto, corresponding biochemical in vitro studies have not been carried out. There is also a lack of information concerning the data at which concentration the tested compounds should be used extracellularly (effective dose) in order to actually inhibit the viral main proteinase intracellularly without being cytotoxic at the same time. This statement is also true for similar in silico studies with plant-derived compounds that are currently being carried out worldwide.

\section{Herpes simplex virus- 1 and herpes simplex virus- 2}

HSV-1 and HSV-2 are highly prevalent in human beings all over the world. HSV-1 is mainly responsible for HSV-induced lesions in the oral cavity and epidermis, while HSV-2 causes genital herpes, a sexually transmitted disease (s. Table 35, Supporting Information). After the primary infection, both viruses establish a lifelong latent infection in the lumbosacral sensory ganglia [91-94]. In the last decade, the inhibitory effects of different EOs and EOCs on the viral replication cycle of acyclovir-sensitive and acyclovir-resistant HSV-1 and/or HSV-2 were described [91-109]. A selection of interesting scientific papers deailing with this subject is listed in Table 1S, Supporting Information. The knowledge gained from the investigations carried out so far allows the conclusion that significant anti-HSV effects could generally be determined when cellfree herpes viruses were pretreated with the test oils for $1 \mathrm{~h}$ before infection of the host cells. For example, pretreatment of cell-free virions with EOs obtained from Illicium verum Hook. f., Melaleuca alternifolia (Maiden \& Betche) Cheel, Leptospermum scoparium J.R. Forst. \& G. Forst., and Matricaria chamomilla L. was found to inhibit the infective ability of acyclovir-sensitive and -resistant HSV strains, indicating the immense antiviral potential of EOs $[93,96]$. In addition, when cell-free HSV-1 particles were pretreated for $1 \mathrm{~h}$ with the maximum non-cytotoxic concentration of lemon balm oil, the virus replication in Vero cells was inhibited by more than $98 \%$ [95]. It can be concluded that lemon balm oil and other EOs (e.g., manuka oil, star anise oil, hyssop oil, TTO, thyme oil, ginger oil, and many others) develop their maximum anti-HSV effects through direct interaction with the infectious virions outside the host cells and thus prevent the viruses from adhering to the cells and/or prevent the viruses from penetrating the cells. This mechanism of action is fundamentally different from the effect of synthetic products (e.g., acyclovir, pencyclovir), which attack only the intracellular replication step of the viruses. This finding suggests that EOs mainly attack the lipid envelope of the viruses. This hypothesis was examined in more detail in two studies on HSV-1. If cell-free virions were incubated with the EO of oregano for $1 \mathrm{~h}$ at room temperature prior to their exposure to host cells, the virions lost their lipid envelope. As a result, these virions could no longer bind to the host cells and thus lost their infectivity [99]. Lai et al. [100] reported a disruption of the lipid envelope of HSV-1 (as visualized via TEM) by carvacrol and thymol at $100 \mu \mathrm{M}$ after $1 \mathrm{~h}$ pretreatment. In contrast to the control experiment, carvacrol disrupted the virus envelopes up to $79 \%$ and thymol reduced the enveloped virus up to $93 \%$.
In some cases, it could be demonstrated that several EOs and EOCs were also able to inhibit early steps as well as late steps in the virus life cycle when added to the host cells after virus infection (posttreatment of virus-infected cells) [92, 101, 102].

\section{Human immunodeficiency virus}

AIDS (acquired immune deficiency syndrome) is caused by infection with the HIV [111]. The HIV-Tat (trans-activator of transcription) is an RNA-binding protein that plays a major role in HIV gene expression and replication [112]. It is a key activator of the virus transcription. Tat interacts with TAR (trans-activation-response element), a specific sequence of the HIV-1 RNA molecule, to enhance transcription of the integrated pro-viral genome. The TatTAR interaction is critical for viral replication and for the emergence of the virus from the latent state. Therefore, the Tat/TARRNA complex could be a target of HIV-1 inhibitors. Feriotto et al. [113] examined the EO-treated Tat/TAR-RNA complex using gel electrophoresis and found that EOs of $T$. vulgaris (complex inhibition at 3.0-6.0 $\mathrm{\mu g} / \mathrm{mL}$ ), Cymbopogon citratus (DC.) Stapf (complex inhibition at $6.0-12.0 \mu \mathrm{g} / \mathrm{mL}$ ), and Rosmarinus officinalis L. (complex inhibition at $0.25-0.50 \mu \mathrm{g} / \mathrm{mL}$ ) interacted directly with Tat protein and destabilized the Tat/TAR-RNA complex.

\section{Dengue virus}

Dengue fever is a tropical and subtropical virus infection that is caused by four antigenetically related serotypes of dengue viruses (DENV-1, DENV-2, DENV-3, DENV-4) [114, 115]. The viruses can be transmitted to humans by infected Aedes mosquitoes such as Aedes aegypti and Aedes albopictus. There are no effective drugs to treat dengue infections. The current exploration of anti-DENV agents is focused on the molecules targeting the host and the virus molecules $[114,115]$.

Ocazionez et al. [117] found that Lippia EOs directly inactivated the cell-free virion particles of all four serotypes of dengue viruses (DENV 1-4) with IC 50 values of $0.4-32.6 \mu \mathrm{g} / \mathrm{mL}$ for Lippia alba and $1.9-33.7 \mu \mathrm{g} / \mathrm{mL}$ for Lippia citriodora. However, no reduction in virus replication was noted when the EO was added to cells previously infected with viruses.

Pajaro-Castro et al. [118] evaluated the antiviral properties of several EO components on DENV-2 replication and DENV-2 proteins. In several in silico molecular docking studies (virus proteinligand docking), $\alpha$-copaene, $\beta$-bourbonene, germacrene $\mathrm{D}$, spathulenol, $\beta$-caryophyllene, caryophyllene oxide, and (+)-epi-bicyclosesquiphellandrene showed significant interactions with different virus proteins [e.g., capsid (C) protein, envelope (E) protein, NS2B, NS3, NS5 polymerase, and NS5 methyltransferase], which are essential for a virus replication cycle (s. Table 1S, Supporting Information). Since $\beta$-caryophyllene showed promising in silico data, it was investigated for its inhibitory effects on DENV-2 replication in vitro. In a virus NS1 reduction assay, $\beta$-caryophyllene inhibited the virus replication in vitro (HepG2 cells; posttreatment of virus-infected cells) at an $\mathrm{IC}_{50}$ value of $22.5 \mu \mathrm{M}$ with a high SI value of 71.1. Thus, $\beta$-caryophyllene seems to be a promising antiDENV-2 candidate that inhibts the virus replication in vitro at an early stage (up to $4 \mathrm{~h}$ post-infection treatment) of the virus replication cycle. 
In a more recent experiment, Flechas et al. [119] screened the antiviral activities of $\beta$-caryophyllene, citral, (R)-(-)-carvone, (S)$(+)$-carvone, $(R)-(+)$-limonene, $p$-cymene, geranyl acetate, nerol, and $\alpha$-phellandrene against DENV serotypes $1-4$ in vitro by measuring the reduction of viral NS1 and cell-surface E proteins in HepG2 and Vero cells. $\beta$-Caryophyllene was found to be the most active compound inhibiting the early steps of the virus life cycle inside the host cells. The compound reduced the formation of the NS1 protein and of the cell-surface E protein of DENV-2 in HepG-2 cells at an IC 50 value of $22.0 \mu \mathrm{M}$. In addition, in Vero cells, $\beta$-caryophyllene reduced the replication of all four serotypes at $\mathrm{IC}_{50}$ values of 8.0 to $15.0 \mu \mathrm{M}$ with high SIs between 5.3 and 10.0.

\section{Bovine viral diarrhea virus}

The BVDV causes a dangerous diarrhea in cattle, especially in calves [122]. Pilau et al. [90] investigated the antiviral effects of Mexican oregano (Lippia graveolens Kunth) EO and its major compound carvacrol on the animal BVDV. The EO and carvacrol were tested at different stages of the virus replication cycle. The most pronounced antiviral effects were seen when the host cells were treated with both Lippia oil or carvacrol after viral inoculation (post-entry treatment) to MDBK cells with $\mathrm{EC}_{50}$ values of 78.0 (SI: 7.2 ) and $50.7 \mu \mathrm{g} / \mathrm{mL}$ (SI: 4.2 ), respectively.

\section{Yellow fever virus}

Yellow fever is an acute viral hemorrhagic disease transmitted by infected Aedes and Haemogogus mosquitoes [125]. In different in vitro studies, the inhibitory effects of the EOs of Lippia origanoides Kunth [126], Lippia citriodora (Palau) Kunth [127] and L. alba (Mill.) N.E.Br. ex Britton \& P.Wilson $[126,127]$ as well as of O. vulgare, Artemisia vulgaris L. [126], and the EOCs citral and limonene [127] on YFV replication were investigated.

Treatment of cell-free virions with the tested EOs for $24 \mathrm{~h}$ prior to host cell infection led to a significant reduction of the virus yields with $\mathrm{IC}_{50}$ values of $3.7 \mu \mathrm{g} / \mathrm{mL}$ (for $L$. alba, L. origanoides, O. vulagare; SI values: $22.9,26.4,26.5$ ) and $11.1 \mu \mathrm{g} / \mathrm{mL}$ (for A. vulgaris; SI value: 8.8) [126]. However, no virus yield reduction was observed when the host cells were pretreated for $24 \mathrm{~h}$ with the tested EOs prior to the virus infection. The results allow the conclusion that the inhibition of YFV infectivity in vitro is based on a direct virion inactivation preventing the adsorption to host cells and a subsequent cellular infection [126].

In a further study, Gomez et al. [127] were able to show that the EO of L. alba inhibited the virus replication cycle before and after the entry of viruses into the host cells. When cell-free yellow fever virions were inoculated with the test oil before the host cell infection, the virus infectivity was significantly reduced $\left(\mathrm{IC}_{50}\right.$ : $4.3 \mu \mathrm{g} / \mathrm{mL}$; SI: 30.6). When the host cells were treated with the test oil after the virus cell infection, the virus titer (PFU/mL) was reduced by $50 \%$ at $15.2 \mu \mathrm{g} / \mathrm{mL}\left(\mathrm{IC}_{50}: 15.2 \mu \mathrm{g} / \mathrm{mL}\right.$; SI: 10.8$)$ with respect to the untreated control. L. citriodora oil and citral also reduced the viral infectivity when the virus was treated before (IC $50: 19.4 / 17.6 \mu \mathrm{g} / \mathrm{mL}$; SI: $2.6 / 1.5)$ and after entry (IC $50: 21.2$ I $25.0 \mu \mathrm{g} / \mathrm{mL}$; SI: $2.4 / 1.1$ ) into the host cells. In contrast to the interpretation of the authors, however, it must be stated that the antiviral activity of $L$. citriodora oil and citral is most likely based on their cytotoxicity, since the SI values of both substances are below the cutoff value of 4.0 (SI values for L. citriodora oil: 2.6 and 2.4; SI values for citral: 1.5 and 1.1).

\section{West Nile virus}

The West Nile virus is a mosquito-borne virus that is able to cause a neuroinvasive disease in human beings and animals [129]. Zamora et al. [129] investigated in vitro the antiviral effects of a CMA (64\% terpinen-4-ol, 14\% p-cymene, 7\% $\alpha$-terpineol, $6 \% \delta$-cadinene, $9 \%$ other monoterpenes) derived from M. alternifolia [against two different strains of WNV (WNVKUNV and WNVNY99)]. CMA showed a significant virucidal effect against both WNV strains in vitro (Vero cells) at the maximum non-cytotoxic concentration of $0.0075 \%$. In comparison to the vehicle control, CMA reduced the virus titer of both WNV strains to about $1.0 \times \log _{10}$ PFU/mL. In addition to its virucidal effect, CMA also exhibited an antiviral activity that decreased the production and/or release of virions from the host cells. In comparison to the vehicle control, the treatment of cells previously infected with viruses (posttreatment of virus-infected cells) with CMA (0.0075\%) significantly reduced the virus titer of both WNV strains inside Vero cells by $2.0 \times \log _{10} \mathrm{PFU} / \mathrm{mL}$.

The disease symptoms of WNV-infected mice closely resemble that of a human infection [130]. When CMA was tested against

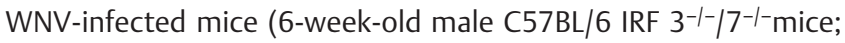
$150 \mu \mathrm{L}$ of $3.0 \%$ CMA per day i. p.) for a period of 6 days, it was found that the test compound significantly reduced the morbidity of the animals and reduced the loss of body weight as well as the virus titers in the brain of the mice [129].

\section{Antiviral Activities of Essential Oils and Essential Oil Compounds against Non-enveloped Viruses}

The capsid in non-enveloped viruses serves to protect the integrity of the viral RNA/DNA and to initiate an infection by adsorbing to the host cells. Up to now, only limited research has looked at the efficacy of EOs against non-enveloped viruses. On the one hand, this is due to the fact that in recent years, EOs have more often been investigated against enveloped viruses and, on the other hand, to the fact that EOs showed little or no effect on non-enveloped viruses. Garozzo et al. [135] found tea tree EO to be ineffective against PV1, echovirus 9, coxsackievirus B1, and adenovirus 2. In addition, Kovac et al. [136] examined in vitro the antiviral activity of hyssop oil (Hyssopus officinalis L.) and marjoram oil (Thymus mastichina (L.) L.) at 0.02 and $0.2 \%$ on non-enveloped viruses such as the murine norovirus and the human adenovirus at different incubation times ( 2 and $24 \mathrm{~h}$ ) and temperatures $\left(+4^{\circ} \mathrm{C}\right.$, room temperature, $\left.37^{\circ} \mathrm{C}\right)$. No significant reduction of the virus titers in host cells (human lung carcinoma A549; mouse macrophage RAW 264.7 cell lines) was observed. Rouis et al. [137] investigated the antiviral activity of the EO from Hypericum triquetrifolium Turra against coxsackievirus B3 on Vero cells (pretreatment of virions/host cells for $1 \mathrm{~h}$ prior to cell/virus infection). The authors found the $\mathrm{EO}$ to be ineffective against coxsackievirus B3 in different non-cytotoxic concentrations. 
However, various EOs have been identified in the last decade that have shown strong antiviral effects against non-enveloped RNA and DNA viruses, such as the murine norovirus, the coxsackievirus, the adenovirus, feline calcivirus, porcine parvovirus, rhinovirus, rotavirus, and some phages (Table 2S, Supporting Information). For the listed viruses and EOs, see also Tables $3 \mathrm{~S}$ and 4S, Supporting Information, respectively. EOs and their active compounds act on the viral capsid to some extent. But it is difficult to determine whether such reductions in the virus infectivity are due to actual damage to the virus particles or to a simple inhibition of virus adsorption to the host cells. For instance, in many cases, the viral RNA was unaffected although the virus was no longer infectious.

\section{Murine norovirus type 1}

MNV-1 infects mice and is virulent, especially in immunocompromised mice. MNV-1 is used as a surrogate to study the biological and physiological behavior of noroviruses [138-140]. In three different in vitro experiments, oregano oil, carvacrol [138], allspice oil, lemongrass oil-1, and citral [139] as well as Artemisia oil-2 (s. Table 4S, Supporting Information) and $\alpha$-thujone [140] were evaluated for their anti-MNV-1 effects in RAW 264.7 cells. Of all the substances tested, carvacrol was found to be the most active one. After exposure of cell-free virions to $0.5 \%$ carvacrol for $1 \mathrm{~h}$ prior to the cell infection, their cell infectivity was significantly inhibited (reduction of the virus titer by $3.87 \times \log _{10} T C I D_{50} / \mathrm{mL}$ ). RNase I protection assays and TEM analyses showed that carvacrol acted directly on the virion capsid and the RNA. Interestingly, after carvacrol treatment, the protein capsids enlarged from about $35 \mathrm{~nm}$ in diameter to $800 \mathrm{~nm}$ [138].

\section{Coxsackievirus}

Coxsackieviruses, named after a town in New York [141], are RNA viruses that are transmitted via droplets or smear infections. There are numerous subtypes, which are simply divided into Coxsackie $A$ and Coxsackie $B$ viruses and which can trigger different clinical pictures such as colds, viral meningitis, and myocarditis.

Elaisi et al. [142] and El-Baz et al. [106] explored in vitro the antiviral activity of EOs of several Eucalyptus species against coxsackievirus B3 and B4. Eucalyptus bicostata Maiden, Blakely \& Simmonds EO showed the best antiviral activity. Pretreatment of the cell-free coxsackievirus B3 for $1 \mathrm{~h}$ prior to the cell infection resulted in a significant reduction of the viral infectivity, with an $\mathrm{IC}_{50}$ value of $0.7 \mathrm{mg} / \mathrm{mL}$ (SI: 22.8) [142].

\section{Porcine parvovirus}

PPV infections (SMEDI syndrome or porcine parvovirose) can lead to significant reproductive failure in pigs. As non-enveloped viruses they are extremely resistant to environmental influences and disinfectants [145]. Chen et al. [145] tested the antiviral effect of germacrone on PPV in swine testis host cells. Germacrone was able to suppress in vitro the synthesis of viral RNA and proteins inside infected cells. In addition, germacrone $(0-200 \mu \mathrm{M})$ inhibited early stages (up to $9 \mathrm{~h}$ post-viral infection) of the PPV replication cycle in a dose-dependent manner (reduction of viral titers: $6.0 \log _{10}$ to $2.5 \log _{10} \mathrm{TCID}_{50} / \mathrm{mL}$ ).

\section{Adenovirus and rhinovirus}

In most cases, rhinoviruses trigger a flu-like infection. However, they are also involved in other respiratory diseases such as sinusitis and bronchitis. In addition to a flu-like infection, adenoviruses can also cause other respiratory diseases (e.g., pneumonia) and be responsible for infections of the gastrointestinal tract and the conjunctiva [60].

Vimalanathan and Hudson [60] investigated the vapor of CLO for its virucidal effects against the virions of adenovirus and rhinovirus 14 . Since respiratory viruses often induce proinflammatory cytokine responses, the authors also explored the anti-cytokine activity of CLO in virus-induced human lung cells. Both viruses were completely inactivated after 60-120 min of exposure to the oil vapor. Furthermore, rhinovirus-induced production of the cytokine IL-6 in human lung epithelial cell monolayers was reduced by more than $50 \%$ after 60 min exposure to the oil vapor.

\section{Feline calicivirus F9}

FCV is a small, non-enveloped virus with single-stranded RNA and typical cup-shaped indentations on the surface from which the name of the virus is derived. It causes mouth ulcers, inflammation of the gums, and nasal discharge in cats [148].

Germacrone [148] as well as Artemisia princeps var. orientalis Hara EO and its main component $\alpha$-thujone [140] were investigated for their anti-FCV-F9 properties. In time-of-drug-addition assays, germacrone was shown to reduce the viral replication in CRFK cells at an early stage of the viral replication cycle in a concentration-dependent manner (e.g., vRNA level was reduced more than $50 \%$ at 60 to $100 \mu \mathrm{M}$ ). In contrast, germacrone did not affect the virion attachment to the host cells or the virion entry into the host cells [148].

In a further study, Chung [140] found that the viral infectivity of FCV-F9 was moderately reduced when the cell-free virions were treated for $1 \mathrm{~h}$ with $0.1 \%$ of $A$. princeps var. orientalis EO (plaque reduction of about $48 \%$ ) or $25 \mathrm{mM} \alpha$-thujone (virus titer reduction of about $1 \times \log _{10} \mathrm{PFU} / \mathrm{mL}$ ) before cell infection.

\section{Nanoencapsulated Essential Oils as Antiviral Agents}

EOs encapsulated in nano-delivery systems could be a successful strategy for combating viral infections. Those EO-based formulations can decrease the volatility of EOs, improve their chemical stability, enhance their water solubility, bioavailabilty, and antiviral efficacy [149-153]. The possibility that nanoencapsulation of EOs will improve their therapeutic effectiveness is currently being discussed $[24,150]$. There are different nanocarriers available, such as polymer-based nanocarriers (nanocapsules/nanoparticles) or lipid-base nanocarriers (e.g., liposomes, lipid-nanoparticles, nanoemulsions) that can be designed in such a way that they possess desirable features for therapy [24, 149-153].

Lai et al. [154] explored the antiviral activity of the pure and the SLNs (glyceryl behenate) incorporated EO of Artemisia arborescens (Vaill.) L. (Artemisia oil-3) against HSV-1 in vitro (co-treatment assay). In addition, the authors investigated both the permeation through and the accumulation into the newborn pig skin strata of 
Artemisia oil-3 (s. Table 4S, Supporting Information) using an in vitro diffusion experiment. The SLN lipidcarrier containing Artemisia oil-3 proved to be a very stable nano-delivery system over a period of 2 years of storage. The in vitro diffusion experiments revealed a high accumulation of Artemisia oil-3 in the pig skin (about $0.3 \mathrm{mg} /$ $\mathrm{m}^{2}$ ) by EO-loaded SLNs, while the oil permeation was not promoted. The latter only took place when the non-encapsulated (pure) oil was used. In contrast to the control (empty SLN carrier), an inhibition of cell infection was observed when HSV-1 and test compounds $(100 \mu \mathrm{g} / \mathrm{mL}$ pure oil or $31.1 \%$ SLN loaded EO) were simultaneously co-added to Vero cells (incubation at $37^{\circ} \mathrm{C}$ ). In both cases the virus infectivity was reduced by $36.2 \%$.

Almeida et al. [155] produced a hydrogel containing volatile Cymbopogon citratus oil ( $\mathrm{CcVO}$ ) encapsulated in poly (d, I-lactideco-glycolide) nanoparticles (HNPVO). In Vero cells, the in vitro anti-herpetic activity of the EO-loaded nanogel (HNPVO: hydrogel, nanoparticles, CcVO), free EO (CcVO), EO-loaded nanoparticles (NPVO), and EO containing hydrogel (HVO) against herpes simplex type 1 and type 2 (HSV-1/HSV-2) were investigated. Vero cells and virions were treated simultaneously with the antiviral test substances. The nanogel protected the encapsulated EO from volatilization, enabled the controlled release from the formulation, and improved its (HNPVO) antiherpetic activity (EC 50 HSV1/2: $0.32 / 0.33 \mu \mathrm{g} / \mathrm{mL}$; SI: 4.67/4.50) compared to the non-encapsulated free CcVO (EC50 HSV-1/2: 11.59/6.69 $\mu \mathrm{g} / \mathrm{mL}$; SI: 9.99/ 17.32), the NPVO (EC50 HSV-1/2: $1.32 / 1.34 \mu \mathrm{g} / \mathrm{mL}$; SI: $9.83 /$ 9.67), and HVO (EC $50: 0.71 \mu \mathrm{g} / \mathrm{mL}$; SI: 2.31$)$.

Vanti et al. [156] investigated the anti-HSV-1 activity of MOEOloaded glycerosomes (glycerol-based vesicles; GS) compared to pure, non-encapsulated MOEO (s. Table 4S, Supporting Information) in vitro. MOEO-GS vesicles exhibited a high chemical and physical stability during 4 months of storage. The MOEO encapsulation efficiency within the glycerosomes was approximately 51.3 and $66.0 \%$ with regard to citral and $\beta$-caryophyllene, respectively. The treatment of cell-free HSV-1 virions with increasing concentrations of MOEO $(0-200 \mu \mathrm{g} / \mathrm{mL})$ or MOEO-GS $(0-600 \mu \mathrm{g} / \mathrm{mL})$ for $1 \mathrm{~h}$ prior to their addition to the Vero cells reduced the viral infectivity in a dose-dependent manner.

WSSV disease is a viral infection of penaeid shrimps. It is highly lethal and contagious, killing the shrimps quickly. Against this background, the following experiment of Junior et al. [157] is particularly noteworthy. The authors fed Litopenaeus vannamei with MTEO (1.05 g thyme EO per $100 \mathrm{~g}$ powder) adsorbed on commercial pellet feed to protect the shrimps against WSSV disease. At $72 \mathrm{~h}$ post-viral infection, the infected shrimps fed with commercial pelleted feed with $1 \%$ MTEO presented an absence of clinical signs of WSSV infection, and their survival rate was significantly higher than that of the control experiments (viral infected shrimps without MTEO or with 0.1 and $0.5 \%$ MTEO treatment).

\section{Conclusions}

Over the past decade, the antiviral effects of EOs and EOCs extracted from various aromatic plants against a variety of RNA and DNA viruses have been well documented in in vitro and in vivo model systems (s. Tables 1S-4S, Supporting Information). Most of the published in vitro experiments deal with enveloped viruses,

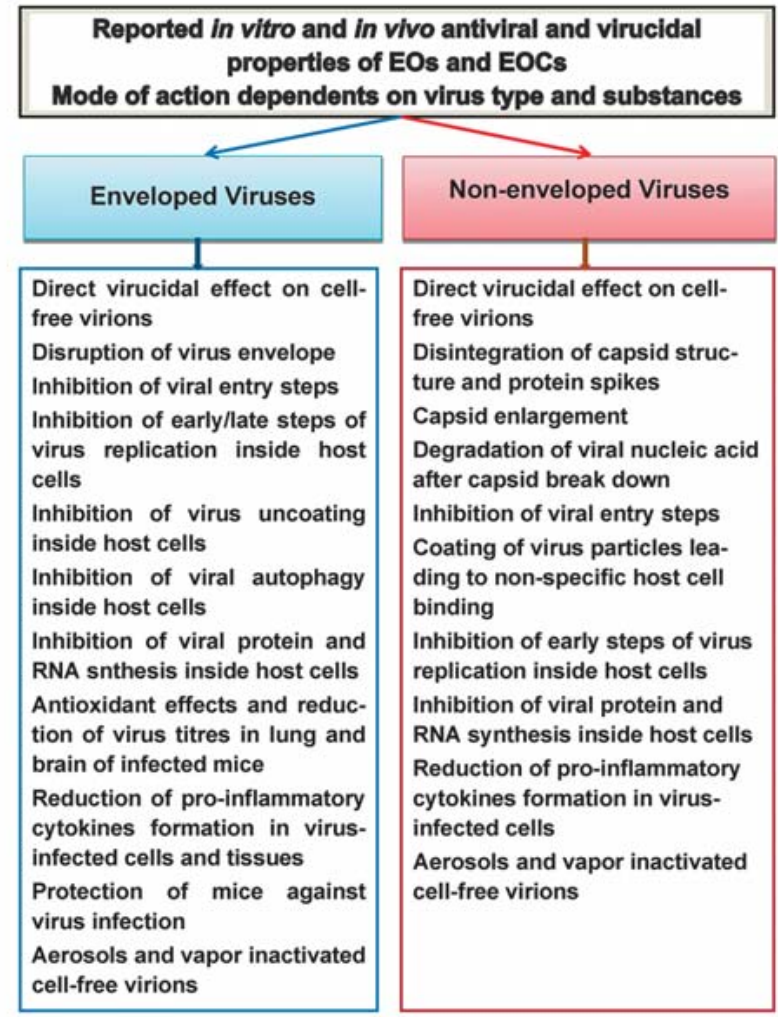

Fig. 3 Summary of the main in vitro and in vivo antiviral and virucidal properties of EOs and EOSs.

in particular, with IFV, AIV, HSV-1, and HSV-2 and to an increasing extent, with SARS-CoV-2. Only a few studies have already evidenced the great antiviral potency of some EOs and EOCs on certain non-enveloped viruses such as coxsackievirus and MNV-1. According to available data, the antiviral and virucidal properties of EOs are usually based on phenolic, alcoholic, and other oxygenated EOCs. In particular, cinnamon oil, clove oil, eucalyptus oil, lemongrass oil, Lippia oil, oregano oil, TTO, thyme oil, and the oil compounds carvacrol, 1,8-cineole, eugenol, germacrone, PA, thymol, terpinen-4-ol ( $\triangleright$ Fig. 2), and some others proved to be particularly effective antiviral/virucidal substances. Studies in mice (or chicks) infected with viruses causing respiratory diseases (e.g., IFV) showed that some EOs (e.g., Mosla oil, Zataria oil) and EOCs (e.g., 1,8-cineole, germacrone, PA) were able to prolong the life of infected animals, reduce the virus titers in brain and lung tissues and significantly inhibit the synthesis of proinflammatory cytokines and chemokines in lung tissues. The most interesting antiviral and virucidal effects of EOs and EOCs on enveloped and non-enveloped viruses are summarized in $>$ Fig. $\mathbf{3}$.

Concerning isolated EOCs, it must be noted that the biochemical world is chiral. The biosynthesis of terpenes in plant tissues is usually stereospecific, with the consequence that many monoand sesquiterpenes are synthesized in defined enantiomeric ratios or as pure enantiomers. It is known from the literature that different enantiomers of a bioactive terpene can act in different ways 
on microbes such as bacteria or fungi [25]. It can therefore be assumed that this also applies to their antiviral activity. But most existing studies on the antiviral effect of EOCs are based on commercially purchased substances, which may not be fully consistent with their fractionated counterparts from natural EOs. Therefore, the effects of stereoisomerism and polarity of isolated EO components on their antiviral effectiveness need to be given more attention in future studies.

The in vitro studies published so far clearly show that the major mechanisms through which EOs and EOCs induce antiviral actions are a direct action on cell-free virions, inhibition of steps involved in the virus attachment, penetration, intracellular replication, and release from the host cells and the inhibition of the vital viral enzymes. In most cases, the greatest antiviral effect was observed when virions were incubated with the drugs for $1 \mathrm{~h}$ or more hours prior to their addition to host cells (pretreatment of cell-free virions), thus indicating a direct effect (virucidal effect) on cellfree virions outside the host cells. Concerning the enveloped virions, one can speculate that the virucidal effect of EOs and EOCs is likely accounted for by disruption of the virus envelope and its associated structures, which are necessary for the virion adsorption to and entry into the host cells. In most cases, the in vitro studies only identified the stages of the virus replication that were inhibited or influenced by EOs and EOCs, while the specific sites of action on and in the host cell as well as the molecular mode of interaction underlying the action were only more intensively investigated in a few cases.

In silico analyzes are used to discover new antiviral and virucidal compounds and to study their bioactive mechanisms. This approach is also useful for estimating the binding affinity of EOCs to viral or host cell proteins to demonstrate and explain their biological effects. Due to the current SARS-CoV-2 pandemic, particularly great efforts have been made to identify suitable molecules that inhibit the entry and replication of the virus in the host cells. With the molecular docking technique, it could be shown that several molecules (e.g., isothymol, organosulfur compounds, 1,8-cineole, jensenone and others) may exert relative strong binding to the viral and host cell-specific target molecules that are indispensable for virus cell adsorption (ACE2, TMPRSS2, RBD), penetration/internalization (RBD), and replication ( $\mathrm{M}^{\text {pro }}$ ). However, validation of the predictions by wet bench data is still missing.

In addition, it is known from available data that the effective time of antiviral action of EOs is limited by their high volatility. The encapsulation of EOs into suitable nano-carrier materials could increase their chemical stability, enhance their water solubility, bioavailabilty, and their antiviral effectiveness. The few studies that have been published on this subject support this assumption but require additional efforts in the future.

\section{Supporting information}

The supporting information includes 4 tables in which the most important experimental results on the antiviral effects of EOs and EOCs (of the last decade) are summarized.

- Tables 1S/2S: Antiviral properties of selected plant EOs and EOCs against different enveloped/non-enveloped viruses.

- Table 3S: List of viruses and their basic characteristics referred in this review.
- Table 4S: List of essential oil-containing medicinal plants reported in this review.

\section{Contributors' Statement}

I am the sole author of this review. The conception and design of the work, the data collection as well as the analysis and interpretation of the data are solely my work.

\section{Acknowledgements}

Thanks go to Dr. Ilse Zündorf, Institute of Pharmaceutical Biology at the University of Frankfurt for the transfer of Figs. 1 and $\mathbf{2}$ and to Dr. Björn Feistel for the generous provision of scientific literature.

\section{Conflict of Interest}

The authors declare that they have no conflict of interest.

\section{References}

[1] Zhong P, Agosto LM, Munro JB, Mothes W. Cell-to-cell transmission of viruses. Curr Opin Virol 2013; 3: 44-50

[2] Nasir A, Romero-Severson E, Claverie JM. Investigating the concept and origin of viruses. Trends Microbiol 2020; 28: 959-967

[3] Jones JE, Le Sage V, Lakdawala SS. Viral and host heterogeneity and their effects on the viral life cycle. Nat Rev Microbiol 2021; 19: 272-282

[4] Rumlova M, Ruml T. In vitro methods for testing antiviral drugs. Biotechnol Adv 2018; 36: 557-576

[5] Louten J. Essential human Virology. Chapter 4: Virus Replication. In: Louten J. Virus Replication. Amsterdam, London: Elsevier, Academic Press; 2016: 49-70

[6] Aoki-Utsubo C, Chen M, Hotta H. Time-of-addition and temperatureshift assays to determine particular step(s) in the viral life cycle that is blocked by antiviral substance(s). BioProtoc 2018; 8: 1-12

[7] De Clercq E, Lia G. Approved antiviral drugs over the past 50 years. Clin Microbiol Rew 2016; 29: 695-747

[8] Bright KR, Gilling DH. Natural virucidal Compounds in Foods. In: Goyal S, Cannon J, eds. Viruses in Foods. Food Microbiology and Food Safety. Cham: Springer; 2016: 449-469

[9] Jones ST. How materials can beat a virus. J Mater Sci 2020; 55: 9148 9151

[10] Kumari CBC, Nagaveni HC. Essential oils of aromatic plants with antifungal, antibacterial, antiviral, and cytotoxic properties - an overview. J Pharmacogn Phytochem 2018; 7: 278-282

[11] Tariq S, Wani S, Rasool W, Bhat M, Prabhakar A, Shalla A, Rather M. A comprehensive review of the antibacterial, antifungal and antiviral potential of essential oils and their chemical constituents against drugresistant microbial pathogens. Microb Pathog 2019; 134: 103580

[12] Ma L, Yao L. Antiviral effects of plant-derived essential oils and their components: An updated review. Molecules 2020; 25: 2627

[13] Reichling J. Plant-microbe Interaction and secondary Metabolites with antiviral, antibacterial and antifungal Properties. In: Wink W, ed. Functions and Biotechnology of Plant secondary Metabolites. West Sussex, United Kingdom: Wiley-Blackwell; 2010: 214-347

[14] Swamy MK, Akhtar MS, Sinniah UR. Antimicrobial properties of plant essential oils against human pathogens and their mode of action: An updated review. Evid Based Complement Alternat Med 2016; 2016: 3012462

[15] Setzer WN. Essential oils as complementary and alternative medicines for the treatment of influenza. Am J Essent Oil Nat Prod 2016; 4: 16-22 
[16] Ebenezer KS, Manivannan R, Punniyamoorthy A, Tamilselvan C. Plant secondary metabolites of antiviral properties a rich medicinal source for drug discovery: A mini review. J Drug Deliv Ther 2019; 9: 161-167

[17] Lelešius R, Karpovaitė A, Mickienė R, Drevinskas T, Tiso N, Ragažinskienė $\mathrm{O}$, Kubilienè L, Maruška A, Šalomskas A. In vitro antiviral activity of fifteen plant extracts against avian infectious bronchitis virus. BMC Vet Res 2019; 15: 178

[18] Ben-Shabat S, Yarmolinsky L, Porat D, Dahancorresponding A. Antiviral effect of phytochemicals from medicinal plants: Applications and drug delivery strategies. Drug Deliv Transl Res 2020; 10: 354-367

[19] Ha TKQ, Lee BW, Nguyen NH, Cho HM, Venkatesan T, Doan TP, Kim E, Oh WK. Antiviral activities of compounds isolated from Pinus densiflora (pine tree) against the influenza A virus. Biomolecules 2020; 10: 711

[20] Kaushik S, Kaushik S, Sharma V, Yadav JP. Antiviral and therapeutic uses of medicinal plants and their derivatives against dengue viruses. Phcog Rev 2018; 12: 177-185

[21] Patra JK, Das G, Bose S, Banerjee S, Vishnuprasad C, Rodrigues-Torres MP, Shin HS. Star anise (Illicium verum): Chemical compounds, antiviral properties, and clinical relevance. Phytother Res 2020; 34: 1248-1267

[22] Wink M. Potential of DNA intercalating alkaloids and other plant secondary metabolites against SARS-CoV-2 causing COVID-19. Diversity 2020; 175: $1-12$

[23] Chouhan S, Sharma K, Guleria S. Antimicrobial activity of some essential oils-present status and future perspectives. Medicines 2017; 4: 58

[24] Paul S, Hmar EBL, Zothantluanga JH, Sharma HK. Essential oils: A review on their salient biological activities and major delivery strategies. Science Vision 2020; 20: 54-71

[25] Reichling J. Anti-biofilm and virulence-factor reducing activities of essential oils and oil components as possible option for bacterial infection control. Planta Med 2020; 86: 520-537

[26] Juergens UR, Dethlefsen, Steinkamp G, Gillissen G, Repges R, Vetter H. Anti-infammatory activity of 1.8-cineol (eucalyptol) in bronchial asthma: A double-blind placebo-controlled trial. Respiratory Med 2003; 97: 250256

[27] Juergens LJ, Worth $\mathrm{H}$, Juergens UR. New perspectives for mucolytic, antiinflammatory and adjunctive therapy with 1,8-cineole in COPD and asthma: Review on the new therapeutic approach. Adv Ther 2020; 37: 17371753

[28] Asif M, Saleem M, Saadullah M, Yaseen HS, Al Zarzour R. COVID-19 and therapy with essential oils having antiviral, anti-inflammatory, and immunomodulatory properties. Inflammopharmacology 2020; 28: 11531161

[29] Sandner G, Heckmann M, Weghuber J. Immunomodulatory activities of selected essential oils. Biomolecules 2020; 10: 1139

[30] Khezri K, Farahpour MR, Mounesi Rad S. Accelerated infected wound healing by topical application of encapsulated rosemary essential oil into nanostructured lipid carriers. Artif Cells Nanomed Biotechnol 2019; 47: 980-988

[31] Cagno V, Donalisio M, Civra A, Cagliero C, Rubiolo P, Lembo D. In vitro evaluation of the antiviral properties of Shilajit and investigation of its mechanisms of action. J Ethnopharmacol 2015; 166: 129-134

[32] Cagno V, Tintori C, Civra A, Cavalli R, Tiberi M, Botta L, Brai A, Poli G, Tapparal C, Lembo D, Botta M. Novel broad spectrum virucidal molecules against enveloped viruses. PLoS One 2018; 13: e0208333

[33] Gu L, Schneller SW, Li Q. Assays for the identification of novel antivirals against Bluetongue virus. J Vis Exp 2013; 80: e50820

[34] Kiyohara H, Ichino C, Kawamura Y, Nagai T, Sato N, Yamada H. Patchouli alcohol: In vitro direct anti-influenza virus sesquiterpene in Pogostemon cablin Benth. J Nat Med 2011; 66: 55-61

[35] Webster RG, Bean W], Gorman OT, Chambers TM, Kawaoka Y. Evolution and ecology of influenza A viruses. Microbiol Rev 1992; 56: 152-179
[36] Samji T. Influenza A: Understanding the viral life cycle. Yale J Biol Med 2009; 82: 153-159

[37] Wu S, Patel KB, Booth L], Metcalf JP, Lin HK, Wu W. Protective essential oil attenuates influenza virus infection: An in vitro study in MDCK cells. BMC Complement Altern Med 2010; 10: 69

[38] Brochot A, Guilbot A, Haddioui L, Roques C. Antibacterial, antifungal, and antiviral effects of three essential oil blends. Microbiol Open 2017; 6: 1-6

[39] Garozzo A, Timpanaro R, Stivala A, Bisignano G, Castro A. Activity of Melaleuca alternifolia (tea tree) oil on influenza virus $A / P R / 8$ : Study on the mechanism of action. Antiviral Res 2010; 89: 83-88

[40] Guinea R, Carrasco L. Concanamycin A blocks influenza virus entry into cells under acidic conditions. FEBS Lett 1994; 349: 327-330

[41] Guinea R, Carrasco L. Requirement for vacuolar proton-ATPase activity during entry of influenza virus into cells. J Virol 1995; 69: 2306-2312

[42] Li X, Duan S, Chu C, Xu J, Zeng G, Lam AK, Zhou J, Yin Y, Fang D, Reynolds MJ, Gu H, jiang L. Melaleuca alternifolia concentrate inhibits in vitro entry of influenza virus into host cells. Molecules 2013; 18: 9550-9566

[43] Wu H, Li B, Wang X, Jin M, Wang G. Inhibitory effect and possible mechanism of action of patchouli alcohol against influenza a (H2N2) virus. Molecules 2011; 16: 6489-6501

[44] Garman E, Laver G. Controlling influenza by inhibiting the virus's neuraminidase. Curr Drug Targets 2004; 5: 119-136

[45] Yu Y, Zhang Y, Wang S, Liu W, Hao C, Wang W. Inhibition effects of patchouli alcohol against influenza a virus through targeting cellular PI3K/Akt and ERK/MAPK signaling pathways. Virol J 2019; 16: 163

[46] Paulpandi M, Kannan S, Thangam R, Kaveri K, Gunasekaran P, Rejeeth C. In vitro anti-viral effect of $\beta$-santalol against influenza viral replication. Phytomedicine 2012; 19: 231-235

[47] Furuse Y, Suzuki A, Kamigaki T, Oshitani H. Evolution of the M gene of the influenza A virus in different host species: Large-scale sequence analysis. Virol J 2009; 6: 67

[48] Gannage M, Dormann D, Albrecht R, Dengjel ], Torossi T, Rämer PC, Lee M, Strowig T, Arrey F, Conenello G, Pypaert M, Andersen J, García-Sastre A, Münz Ch. Matrix protein 2 of influenza A virus blocks autophagosome fusion with lysosomes. Cell Host Microbe 2009; 6: 367-380

[49] Wu QF, Wang W, Daia XY, Wang ZY, Shen ZH, Ying HZ, Yuc CH. Chemical compositions and anti-influenza activities of essential oils from Mosla dianthera. J Ethnopharmacol 2012; 139: 668-671

[50] Dai JP, Zhao XF, Zeng J, Wan Q, Yang JC, Li WZ, Chen XX, Wang GF, Li KS Drug screening for autophagy inhibitors based on the dissociation of beclin1-Bcl2 complex using BiFC technique and mechanism of eugenol on anti-influenza A virus activity. PLoS One 2013; 8: e61026

[51] Wang R, Zhu Y, Zhao J, Ren Ch, Li P, Chen H, Jin M, Zhou H. Autophagy promotes replication of influenza A virus in vitro. J Virol 2019; 93: e01984-18

[52] Liao Q, Qian Z, Liu R, An L, Chen X. Germacrone inhibits early stages of influenza virus infection. Antiviral Res 2013; 100: 578-588

[53] He YQ, Caib L, Qiana QG, Yanga SH, Chena DL, Zhaoa BQ, Zhongc ZP, Zhoua XJ. Anti-influenza A (H1N1) viral and cytotoxic sesquiterpenes from Carpesium abrotanoides. Phytochem Lett 2020; 35: 41-45

[54] Li Y, Lai Y, Wang Y, Liu N, Zhang F, Xu P. 1,8-Cineol protect against influenza-virus-induced pneumonia in mice. Inflammation 2016; 39: 1582 1592

[55] Choi HJ. Chemical constituents of essential oils possessing anti-influenza A/WS/33 virus activity. Osong Public Health Res Perspect 2018; 9: 348353

[56] Tellier R. Review of aerosol transmission of influenza A virus. Emerg Infect Dis 2006; 12: 1657-1662

[57] Richard M, van den Brand JMA, Bestebroer TM, Lexmond P, de Meulder D, Fouchier RAM, Lowen AC, Herfst S. Influenza A viruses are transmitted 
via the air from the nasal respiratory epithelium of ferrets. Nat Commun 2020; $11: 766$

[58] Usachev EV, Pyankov OV, Usacheva OV, Agranovski IE. Antiviral activity of tea tree and eucalyptus oil aerosol and vapor. J Aerosol Sci 2013; 59: $22-30$

[59] Vimalanathan S, Hudson J. Anti-influenza virus activity of essential oils and vapors. Am J Essent Oil Nat Prod 2014; 2: 47-53

[60] Vimalanathan S, Hudson J. The activity of cedar leaf oil vapor gainst respiratory viruses: Practical applications. J App Pharm Sci 2013; 3: 011-015

[61] Pyankov OV, Usachev EV, Pyankova O, Agranovski IE. Inactivation of airborne influenza virus by tea tree and eucalyptus oils. Aerosol Sci Technol 2012; 46: 1295-1302

[62] Abdel-Moneim AS, Manal AA, El-Kady MF. Isolation and mutation trend analysis of influenza A virus subtype H9N2 in Egypt. Virol J 2012; 9: 173

[63] Ibrahim NA, El-Hawary SS, Mohammed MMD, Farid MA, Abdel-Wahed NAM, Ali MA, El-Abd EAW. Chemical composition, antiviral against avian influenza (H5N1) virus and antimicrobial activities of the essential oils of the leaves and fruits of Fortunella margarita Lour. Swingle, growing in Egypt. J Appl Pharm Sci 2015; 5: 6-12

[64] Pourghanbari G, Nili H, Moattari A, Mohammadi A, Iraji A. Antiviral activity of the oseltamivir and Melissa officinalis L. essential oil against avian influenza A virus (H9N2). Virusdisease 2016; 27: 170-178

[65] Kumosani T, Obeid Y, Shaib H, Abualnaja K, Moselhy SS, Iyer A, Sultan R, Aslam A, Anjum A, Barbour E. Standardization of a protocol for quantitative evaluation of anti-aerosolized influenza virus activity by vapors of a chemically-characterized essential oil blend. Prev Infect Control 2017; 3: $6-14$

[66] Shayeganmehr A, Vasfi Marandi M, Karimi V, Barin A, Ghalyanchilangeroudi A. Zataria multiflora essential oil reduces replication rate of avian influenza virus (H9N2 subtype) in challenged broiler chicks. Br Poult Sci 2018; 59: 389-395

[67] Chandevar P, Chavhan B, Sahare A, Deshpande P, Kawade D. SARS coronavirus: A review of threat in global world. Inter J Pharm Sci Res 2020; 5: 1-9

[68] Al-Garawyi AMA, Hussein TA, Jassim MMA. Inhibition of viral infection by using of natural herbal remedies as alternative treatment. Sys Rev Pharm 2020; 11: 416-419

[69] Merad M, Martin JC. Pathological inflammation in patients with COVID-19: A key role for monocytes and macrophages. Immunology 2020; 20: 355-362

[70] Antonio AS, Wiedemann LSM, Veiga-Junior VF. Natural products' role against COVID-19. RSC Adv 2020; 10: 23379-23393

[71] Verma S, Twilley D, Esmear T, Oosthuizen CB, Reid AM, Nel M, Lall N. Anti-SARS-CoV natural products with the potential to inhibit SARSCoV-2 (COVID-19). Front Pharmacol 2020; 11: 561334

[72] Silveira D, Prieto-Garcia JM, Boylan F, Estrata O, Fonseca-Bazzo YM, Jamal CM, Magalhaes PO, Pereira EO, Tomczyk M, Heinrich M. COVID-19: Is there evidence for the use of herbal medicines as adjuvant symptomatic therapy? Front Pharmacol 2020; 11: 581840

[73] Panyod S, Ho CT, Sheen LY. Dietary therapy and herbal medicine for COVID-19 prevention: A review and perspective. J Tradit Complement Med 2020; 10: 420-427

[74] Nadjib BM. Effective antiviral activity of essential oils and their characteristic terpenes against coronaviruses: An update. J Pharmacol Clin Toxicol 2020; 8: 1138

[75] Flouchi R, Fikri-Benbrahim K. Prevention of COVID 19 by aromatic and medicinal plants: A systematic review. J Pharm Sci Res 2020; 12: 11061111

[76] Loizzo MR, Saab AM, Tundis R, Statti GA, Menichini F, Lampronti I, Gambari R, Cinatl J, Doerr HW. Phytochemical analysis and in vitro antiviral activities of the essential oils of seven Lebanon species. Chem Biodivers 2008; 5: 461-470
[77] Abdelli I, Hassanic F, Brikcic SB, Ghalem S. In silico study the inhibition of angiotensin converting enzyme 2 receptor of COVID-19 by Ammoides verticillata components harvested from Western Algeria. J Biomol Struct Dyn 2021; 39: 3263-3276

[78] Thuy BTP, Ai My TT, Hai NTT, Hieu LT, Hoa TT, Loan HTP, Triet NT, Van Anh TT, Quy PT, Tat PV, Hue NV, Quang DT, Trung NT, Tung VT, Huynh LK, Nhung NTA. Investigation into SARS-CoV-2 resistance of compounds in garlic essential oil. ACS Omega 2020; 5: 8312-8320

[79] Da Silva JKR, Figueiredo PLB2, Byler KG, Setzer WN. Essential oils as antiviral agents, potential of essential oils to treat SARS-CoV-2 infection: An in-silico investigation. Int ] Mol Sci 2020; 21: 3426

[80] My TTA, Loan HTP, Hai NTT, Hieu LT, Hoa TT, Thuy BTP, Quang DT, Triet NT, Anh TTV, Dieu NTX, Trung NT, Hue NV, Tat PV, Tung VT, Nhung NTA. Evaluation of the inhibitory activities of COVID-19 of Melaleuca cajuputi oil using docking simulation. ChemistrySelect 2020; 5: 6312-6320

[81] Kumar KJS, Vani MG, Wang CS, Chen CC, Chen YC, Lu LP, Huang CH, La CS, Wang SY. Geranium and lemon essential oils and their active compounds downregulate angiotensin-converting enzyme 2 (ACE2), a SARS-CoV-2 spike receptor-binding domain, in epithelial cells. Plants 2020; 9: 770

[82] Sharma AD, Kaur I. Eucalyptol (1,8-cineole) from eucalyptus essential oil a potential inhibitor of COVID 19 corona virus infection by molecular docking studies. Preprints 2020. doi:10.20944/preprints202003.0455. v1

[83] Sharma AD, Kaur I. Jensenone from eucalyptus essential oil as a potential inhibitor of COVID 19 corona virus infection. Res Rev Biotech Biosci 2020; 7: 59-66

[84] Kumar A, Choudhir G, Shukla SK, Sharma M, Tyagi P, Bhushan A, Rathore M. Identification of phytochemical inhibitors against main protease of COVID-19 using molecular modeling approaches. I Biomol Struct Dyn 2020. doi:10.1080/07391102.2020.1772112

[85] Walls AC, Park Y], Tortorici MA, Wall A, McGuire AT, Veesler D. Structure function and antigenicity of the SARS-CoV-2 spike glycoprotein. Cell 2020; 181: 281-292

[86] Kulkarni SA, Nagarajan SK, Ramesh V, Palaniyandi V, Selvam SP, Madhavan T. Computational evaluation of major components from plant essential oils as potent inhibitors of SARS-CoV-2 spike protein. J Mol Struct 2020; 1221: 128823

[87] De Jesus M, Gaza JT, Junio H, Nellas R. Molecular docking studies of aromatherapy oils against SARS-CoV-2. Preprint 2020; 15: 26

[88] Feng J, Bai X, Cui T, Zhou H, Chen Y, Xie J, Shi Q, Wang H, Zhang G. In vitro antiviral activity of germacrone against porcine reproductive and respiratory syndrome virus. Curr Microbiol 2016; 73: 317-323

[89] Fabros DM, Kankeaw U, Ruansit W, Tonlek B, Theenongsang S, Charerntantanakul W. Evaluation of antiviral potential of cinnamon essential oil and its derived benzimidazole against porcine reproductive and respiratory syndrome virus. J Agric Res Ext 2018; 35 (Suppl.): 21-31

[90] Pilau MR, Alves SH, Weiblen R, Arenhart S, Cueto AP, Lovato LT. Antivira activity of the Lippia graveolens (Mexican oregano) essential oil and its main compound carvacrol against human and animal viruses. Braz Jicrobiol 2011; 42: 1616-1624

[91] Reichling J. Antibacterial and antiviral Effects of aromatic Plant-derived essential Oils - a scientific and medicinal Approach. In: Rai M, Cordell GA, Martinez JL, Marinoff M, Rastrelli L, eds. Medicinal Plants - Biodiversity and Drugs. Boca Raton: CRC Press; 2012: 622-640

[92] Cagno V, Sgorbini B, Sanna C, Cagliero C, Ballero M, Civra A, Donalisio M, Bicchi C, Lembo D, Rubioloet P. In vitro anti-herpes simplex virus-2 activity of Salvia desoleana Atzei \& V. Picci essential oil. PLoS One 2017; 12: e0172322

[93] Schnitzler P. Essential oils for the treatment of herpes simplex virus infections. Chemotherapy 2019; 64: 1-7 
[94] Álvarez DM, Castillo E, Duarte LF, Arriagada J, Corrales N, Farías MA, Henríquez A, Agurto-Muñoz C, González PA. Current antivirals and novel botanical molecules interfering with herpes simplex virus infection. Front Microbiol 2020; 11: 139

[95] Schnitzler P, Schumacher A, Reichling J. Melissa officinalis oil affects infectivity of enveloped herpesviruses. Phytomedicine 2008; 15: 734740

[96] Schnitzler P, Astani A, Reichling J. Antiviral Effects of Plant-derived essential Oils and pure Oil Components. In: Halldor T, ed. Lipids and essential Oils as antimicrobial Agents. West Sussex, United Kingdom: John Wiley \& Sons, Ltd.; 2011: 239-254

[97] Brand YM, Roa-Linares VC, Betancur-Galvis LA, Durán-García DC, Stashenko E. Antiviral activity of Colombian labiatae and verbenaceae family essential oils and monoterpenes on human herpes viruses. J Essent Oil Res 2016; 28: 130-137

[98] Walaszek R, Marszalek A, Kasperczyk T, Walaszek K, Burdacki M. The efficacy of aromatherapy in prevention of herpes simplex virus infections. Ind J Trad Knowledge 2018; 17: 425-429

[99] Siddiqui YM, Ettayebi M, Haddad AM, Al-Ahdal MN. Effect of essential oils on the enveloped viruses: Antiviral activity of oregano and clove oils on herpes simplex virus type 1 and Newcastle disease virus. Med Sci Res 1996; 24: 185-186

[100] Lai WL, Chuang HS, Lee MH, Wei CL, Lin CF, Tsai YC. Inhibition of herpes simplex virus type 1 by thymol-related monoterpenoids. Planta Med 2012; 78: 1636-1638

[101] Civitelli L, Panella S, Marcocci ME, De Petris A, Garzoli S, Pepi F, Vavala E, Ragno R, Nencioni L, Palamara AT, Angiolella L. In vitro inhibition of herpes simplex virus type 1 replication by Mentha suaveolens essential oil and its main component piperitenone oxide. Phytomedicine 2014; 21: $857-865$

[102] Venturi CR, Danielli LJ, Klein F, Apel MA, Montanha JA, Bordignon SAL, Roehe PM, Fuentefria AM, Henriques AT. Chemical analysis and in vitro antiviral and antifungal activities of essential oils from Glechon spathulata and Glechon marifolia. Pharm Biol 2015; 53: 682-688

[103] Astani A, Reichling J, Schnitzler P. Comparative study on the antiviral activity of selected monoterpenes derived from essential oils. Phytother Res 2010; 24: 673-679

[104] Astani A, Reichling J, Schnitzler P. Screening for antiviral activities of isolated compounds form essential oils. Evid Based Complement Alternat Med 2011; 2011: 253643

[105] Astani A, Schnitzler P. Antiviral activity of monoterpenes beta-pinene and limonene against herpes simplex virus in vitro. Iran J Microbiol 2014; 3: 150-155

[106] El-Baz FK, Mahmoud K, El-Senousy WM, Darwesh OM, El Gohary AE. Antiviral-antimicrobial and schistosomicidal activities of Eucalyptus camaldulensis essential oils. Int J Pharm Sci Rev Res 2015; 31: 262-268

[107] Gavanji S, Sayedipour SS, Larki B, Bakhtaric A. Antiviral activity of some plant oils against herpes simplex virus type 1 in Vero cell culture. J Acute Med 2015; 5: 62-68

[108] Sharifi-Rad J, Salehi B, Schnitzler P, Ayatollahi SA, Kobarfard F, Fathi M, Eisazadeh M, Sharifi-Rad M. Susceptibility of herpes simplex virus type 1 to monoterpenes thymol, carvacrol, $p$-cymene and essential oils of Sinapis arvensis L., Lallemantia royleana Benth. and Pulicaria vulgaris Gaertn. Cell Mol Biol (Noisy le Grand) 2017; 63: 41-46

[109] Kamalabadi M, Astani A, Nemati F. Antiviral effect and mechanism of carvacrol on herpes simplex virus type 1. Int J Med Lab 2018; 5: 113122

[110] Camero M, Lanave G, Catella C, Capozza P, Gentile A, Fracchiolla G, Britti D, Martella V, Buonavoglia C, Tempesta M. Virucidal activity of ginger essential oil against caprine alphaherpesvirus-1. Vet Microbiol 2019; 230: 150-155

[111] Douek DC, Roederer M, Koup RA. Emerging concepts in the immunopathogenesis of AIDS. Annu Rev Med 2009; 60: 471-484
[112] Das AT, Harwig A, Berkhout B. The HIV-1 Tat protein has a versatile role in activating viral transcription. J Virol 2011; 85: 9506-9516

[113] Feriotto G, Marchetti N, Costa V, Beninati S, Tagliati F, Mischiati C. Chemical composition of essential oils from Thymus vulgaris, Cymbopogon citratus, and Rosmarinus officinalis, and their effects on the HIV-1 Tat protein function. Chem Biodivers 2018; 15: e1700436

[114] Kaushik S, Kaushik S, Sharma V, Yadav JP. Antiviral and therapeutic uses of medicinal plants and their derivatives against dengue viruses. Phcog Rev 2018; 12: 177-185

[115] Kadir SLA, Yaakop H, Zulkiffi RM. Potential anti-dengue medicinal plants: A review. J Nat Med 2013; 67: 677-689

[116] García CC, Acosta EG, Carro AC, Belmonte MCF, Bomben R, Duschatzky CB, Perotti M, Schuff C, Damonte EB. Virucidal activity and chemical composition of essential oils from aromatic plants of central west argentina. Nat Prod Commun 2010; 5: 1307-1310

[117] Ocazionez RE, Meneses R, Torres FA, Stashenko E. Virucidal activity of Colombian Lippia essential oils on dengue virus replication in-vitro. Mem Inst Oswaldo Cruz 2010; 105: 304-309

[118] Pajaro-Castro N, Flechas MC, Ocazionez R, Stashenko E, OliveroVerbel J. Potential interaction of components from essential oils with dengue virus proteins. Bol Latinoam Caribe Plant Med Aromat 2015; 14: $141-155$

[119] Flechas MC, Ocazionez RE, Stashenko EE. Evaluation of in vitro antiviral activity of essential oil compounds against dengue virus. Pharmacogn J 2018; 10: 55-59

[120] Vogt MV, Sutil SB, Escobar FM, Sabini MC, Cariddi LN, Torres CV, Zanon SM, Sabini LI. Minthostachys verticillata essentials oil and its major components: Antiherpetic selective action in HEp-2 cells. Mol Med Chem 2010; $21: 117-120$

[121] He W, Zhai X, Su J, Ye R, Zheng Y, Su S. Antiviral activity of germacrone against pseudorabies virus in vitro. Pathogens 2019; 8: 258

[122] Khodakaram-Tafti A, Faranikish GH. Persistent bovine viral diarrhea virus (BVDV) infection in cattle herds. Iran J Vet Res 2017; 18: 154-163

[123] Kubiça TF, Alves SH, Weiblen R, Lovato LT. In vitro inhibition of the bovine viral diarrhoea virus by the essential oil of Ocimum basilicum (basil) and monoterpenes. Brazilian J Microbiol 2014; 45: 209-214

[124] Roy S, Chaurvedi P, Chowdhary A. Evaluation of antiviral activity of essential oil of Trachyspermum ammi against lapanese encephalitis virus. Pharmacognosy Res 2015; 7: 263-267

[125] Monath TP, Barrett AD. Pathogenesis and pathophysiology of yellow fever. Adv Virus Res 2003; 60: 343-395

[126] Meneses R, Ocazionez RE, Martínez JR, Stashenko EE. Inhibitory effect of essential oils obtained from plants grown in Colombia on yellow fever virus replication in-vitro. Ann Clin Microbiol Antimicrob 2009; 8: 8

[127] Gómez LA, Stashenko E, Ocazionez RE. Comparative study on in vitro activities of citral, limonene and essential oils from Lippia citriodora and L. alba on yellow fever virus. Nat Prod Commun 2013; 8: 249-252

[128] Mohammadi A, Mosleh N, Shomali T, Ahmadi M, Sabetghadam S. In-vitro evaluation of antiviral activity of essential oil from Zataria multiflora Boiss. against Newcastle disease virus. J Herb Med Pharmacol 2015; 4: 71-74

[129] Zamora AP, Edmonds JH, Reynolds MJ, Khromykh AA, Ralph S]. The in vitro and in vivo antiviral properties of combined monoterpene alcohols against West Nile virus infection. Virology 2016; 495: 18-32

[130] Samuel MA, Diamond MS. Pathogenesis of West Nile virus infection: A balance between virulence, innate and adaptive immunity, and viral evasion. J Virol 2006; 80: 9349-9360

[131] Zeedan GSG, Abdalhamed AM, Ottai ME, Abdelshafy S, Abdeen E. Antimicrobial, antiviral activity and GC-MS analysis of essential oil extracted from Achillea fragrantissima plant growing in Sinai Peninsula, Egypt. J Microbial Biochem Technol 2014; S8: 006 
[132] Ralambondrainy M, Belarbi E, Viranaicken W, Baranauskienė R, Venskutonis PR, Desprès P, Roques P, El Kalamouni C, Selambarom J. In-vitro comparison of three common essential oils mosquito repellents as inhibitors of the Ross River virus. PLoS One 2018; 13: e0196757

[133] Haddad JG, Picard M, Bénard S, Desvignes C, Desprès P, Diotel N, El Kalamouni C. Ayapana triplinervis essential oil and its main component thymohydroquinone dimethyl ether inhibit Zika virus at doses devoid of toxicity in zebrafish. Molecules 2019; 24: 3447

[134] Lane T, Anantpadma M, Freundlich JS, Davey RA, Madrid PB, Ekins S. The natural product eugenol is an inhibitor of the ebola virus in-vitro. Pharm Res 2019; 36: 104

[135] Garozzo A, Timpanaro R, Bisignano B, Furneri PM, Bisignano G, Castro. In vitro antiviral activity of Melaleuca alternifolia essential oil. Lett Appl Microbiol 2009; 49: 806-808

[136] Kovac K, Diez-Valcarce M, Raspor P, Hernándes M, Rodriques-Lazáro D. Natural plant essential oils do not inactivate non-enveloped enteric viruses. Food Environ Virol 2012; 4: 209-212

[137] Rouis Z, Abid N, Koudja S, Yangui T, Elaissi A, Cioni PL, Flamini G, Aouni M. Evaluation of the cytotoxic effect and antibacterial, antifungal, and antiviral activities of Hypericum triquetrifolium Turra essential oils from Tunisia. BMC Complement Altern Med 2013; 13: 24

[138] Gilling DH, Kitajima M, Torrey JR, Bright KR. Antiviral efficacy and mechanisms of action of oregano essential oil and its primary component carvacrol against murine norovirus. J Appl Microbiol 2014; 116: 1149-1163

[139] Gilling DH, Kitajima M, Torrey JR, Bright KR. Mechanisms of antiviral action of plant antimicrobials against murine norovirus. Appl Environ Microbiol 2014; 80: 4898-4910

[140] Chung MS. Antiviral activities of Artemisia princeps var. orientalis essential oil and its $\alpha$-thujone against norovirus surrogates. Food Sci Biotechnol 2017; 26: 1457-1461

[141] Dalldorf G, Sickles GM. An unidentified, filtrable agent isolated from the feces of children with paralysis. Science 1948; 108: 61-62

[142] Elaissi A, Rouis Z, Salem NAB, Mabrouk S, Ben Salem Y, Salah KBH, Aouni M, Farhat F, Chemli R, Harzallah-Skhiri F, Khouja ML. Chemical composition of 8 Eucalyptus species' essential oils and the evaluation of their antibacterial, antifungal and antiviral activities. BMC Complement Altern Med 2012; 12: 81

[143] Bouazzi S, Jmii H, El Mokni R, Faidi K, Falconieri D, Piras A, Jaïdane H, Porcedda S, Hammami S. Cytotoxic and antiviral activities of the essential oils from Tunisian fern, Osmunda regalis. S Afr J Bot 2018; 118: 5257

[144] El Mokni R, Youssef FS, Jmii H, Khmiri A, Bouazzi S, Jlassi I, Jaidane H, Dhaouadi H, Ashour ML, Hammami S. The essential oil of Tunisian Dys- phania ambrosioides and its antimicrobial and antiviral properties. J Essent Oil Bear Plants 2019; 22: 282-294

[145] Chen Y, Dong Y, Jiao Y, Hou L, Shi Y, Gu T, Zhou P, Shi Z, Xu L, Wang C. In vitro antiviral activity of germacrone against porcine parvovirus. Arch Virol 2015; 160: 1415-1420

[146] Oskuee RK, Behravan J, Ramezani M. Chemical composition, antimicrobial activity and antiviral activity of essential oil of Carum copticum from Iran. Avicenna J Phytomedicine 2011; 1: 83-90

[147] Behravan J, Ramezani M, Nobandegani EF, Gharaee ME. Antiviral and antimicrobial activity of Thymus transcaspicus essential oil. Pharmacologyonline 2011; 1: 1190-1199

[148] Wu H, Liu Y, Zu S, Sun X, Liu C, Liu D, Zhang X, Tian J, Qu L. In vitro antiviral effect of germacrone on feline calicivirus. Arch Virol 2016; 161: 1559-1567

[149] Bilia AR, Guccione C, Isacchi B, Righeschi C, Firenzuoli F, Bergonzi MC. Essential oils loaded in nanosystems: A developing strategy for a successful therapeutic approach. Evid Based Complement Alternat Med 2014; 2014: 651593

[150] Rai M, Paralikar P, Jogee P, Agarkar G, Ingle AP, Derita M, Zacchino S. Synergistic antimicrobial potential of essential oils in combination with nanoparticles: Emerging trends and future perspectives. Intern J Pharm 2017; 519: 67-78

[151] De Matos SP, Teixeira HF, de Lima AAN, Veiga-Junior VF, Koester LS Essential oils and isolated terpenes in nanosystems designed for topical administration: A review. Biomolecules 2019; 9: 138

[152] Chakravarty M, Vora A. Nanotechnology-based antiviral therapeutics. Drug Deliv Transl Res 2021; 11: 748-787

[153] Lammari N, Louaer O, Meniai AH, Elaissari A. Encapsulation of essentia oils via nanoprecipitation process: Overview, progress, challenges and prospects. Pharmaceutics 2020; 12: 431

[154] Lai F, Sinico C, De Logu A, Zaru M, Müller RH, Fadda AM. SLN as a topical delivery system for Artemisia arborescens essential oil: In vitro antiviral activity and skin permeation study. Int J Nanomedicine 2007; 2: 419-425

[155] Almeida KB, Araujo JL, Cavalcanti JF, Romanos MTV, Mourão SC, Amaral ACF, Falcão DQ. In vitro release and anti-herpetic activity of Cymbopogon citratus volatile oil-loaded nanogel. Rev Bras Farmacogn 2018; 28: 495-502

[156] Vanti G, Ntallis SG, Panagiotidis CA, Dourdouni V, Patsoura C, Bergonz MC, Lazari D, Bilia AR. Glycerosome of Melissa officinalis L. essential oil for effective anti-HSV type 1. Molecules 2020; 25: 3111

[157] Junior OT, Kuhn F, Padilha PJM, Nesi CN, Mestres M, Magro JD, Castellv SDL. Effect of microencapsulated thyme essential oil on white spot virus-infected Litopenaeus vannamei. Aquacult Int 2018; 26: 1459-1468 